University of Nebraska - Lincoln

DigitalCommons@University of Nebraska - Lincoln

Papers in the Earth and Atmospheric Sciences

Earth and Atmospheric Sciences, Department

7-1975

\title{
GEOCHEMISTRY OF THE CENOZOIC VOLCANIC ROCKS OF ROSS ISLAND AND VICINITY, ANTARCTICA
}

S. S. Goldich

Northern Illinois University

S. B. Treves

University of Nebraska-Lincoln

N. H. Suhr

Pennsylvania State University - Main Campus

J. S. Stuckless

US Geological Survey, Denver, CO

Follow this and additional works at: https://digitalcommons.unl.edu/geosciencefacpub

Part of the Earth Sciences Commons

Goldich, S. S.; Treves, S. B.; Suhr, N. H.; and Stuckless, J. S., "GEOCHEMISTRY OF THE CENOZOIC VOLCANIC ROCKS OF ROSS ISLAND AND VICINITY, ANTARCTICA" (1975). Papers in the Earth and Atmospheric Sciences. 332.

https://digitalcommons.unl.edu/geosciencefacpub/332

This Article is brought to you for free and open access by the Earth and Atmospheric Sciences, Department of at DigitalCommons@University of Nebraska - Lincoln. It has been accepted for inclusion in Papers in the Earth and Atmospheric Sciences by an authorized administrator of DigitalCommons@University of Nebraska - Lincoln. 


\title{
THE JOURNAL OF GEOLOGY
}

$$
\text { July } 1975
$$

\section{GEOCHEMISTRY OF THE CENOZOIC VOLCANIC ROCKS OF ROSS ISLAND AND VICINITY, ANTARCTICA ${ }^{1}$}

\author{
S. S. GOLDICH, S. B. TREVES, N. H. SUHR, AND J. S. STUCKLESS ${ }^{2}$
}

Northern Illinois University, DeKalb, Illinois 60115; University of Nebraska, Lincoln, Nebraska 68508; and Pennsylvania State University, University Park, Pennsylvania 16802

\section{ABSTRACT}

The Cenozoic volcanic rocks of Ross Island and vicinity, Antarctica, are surface flows, tuffs, breccias, and small intrusives. The prominent rock is basanitoid. Alkali-basalt magma reached the surface over an appreciable length of time and was differentiated to produce a rock series: basanitoid $\rightarrow$ trachybasalt $\rightarrow$ phonolite. The alkalic, silica-undersaturated rocks are part of a larger petrologic province composed of volcanic centers in a belt nearly $2,000 \mathrm{~km}$ long roughly parallel to the Transantarctic Mountains. Two trends of magmatic differentiation are apparent. At depth the fractional crystallization of olivine, clinopyroxene, and opaque oxide minerals, all of which are abundant as phenocrysts in the basanitoid flows, produced trachybasalt magma. At crustal levels, fractional crystallization of clinopyroxene, apatite, opaque oxides, kaersutite, plagioclase, and anorthoclase developed the phonolitic rocks. Alkali enrichment is marked, and the end-member phonolites contain $11 \% \mathrm{Na}_{2} \mathrm{O}, 5.6 \% \mathrm{~K}_{2} \mathrm{O}$, and $57 \% \mathrm{SiO}_{2}$. The basanitoids contain relatively large amounts of $\mathrm{Ba}$ ( $\sim 400 \mathrm{ppm})$, Sr ( 1,000 ppm), and $\mathrm{Rb}(\sim 30 \mathrm{ppm})$. The concentrations of these and other trace elements in the various rock types support the model of small degrees of partial melting of peridotitic mantle for the derivation of the basanitoid magma, and of magmatic differentiation for the subsequent development of the rock series.

\section{INTRODUCTION}

Twenty-nine samples of volcanic rocks from Ross Island and vicinity in Antarctica (fig. 1) were analyzed for major, minor, and trace constituents. This study is part of the Dry Valley Drilling Project (DVDP), a cooperative program sponsored by Japan, New Zealand, and the United States, and was undertaken to obtain information on the exposed volcanic rocks that might be encountered in drilling. The samples were collected by Treves during five field seasons from 1960 to 1971 .

\footnotetext{
1 Manuscript received September 5, 1974; revised October 29, 1974.

2 Present address: U.S. Geological Survey, Denver, Colorado 80225.
}

[Journal of Geology, 1975, Vol. 83, p. 415-435] (c) 1975 by the University of Chicago. All rights reserved.
Locations are shown on figures 2 and 3, except for sample 5 (fig. 1).

The volcanic rocks of the Ross Island region are part of a larger province that extends for a distance of nearly $2,000 \mathrm{~km}$ from Mt. Weaver to the Balleny Islands and is roughly parallel to the Transantarctic Mountains (fig. 1). Hamilton (1972) suggested that the volcanic belt might be called the Ross Sea petrologic province with three major subdivisions: (1) McMurdo, (2) Hallett, and (3) Balleny volcanic provinces. He gave excellent descriptions of the larger features of the major volcanic centers and noted that the McMurdo volcanic province is characterized by high subaerial volcanoes. To the north in the Hallett province, the volcanic rocks are subglacial domes and low subaerial volcanoes. 


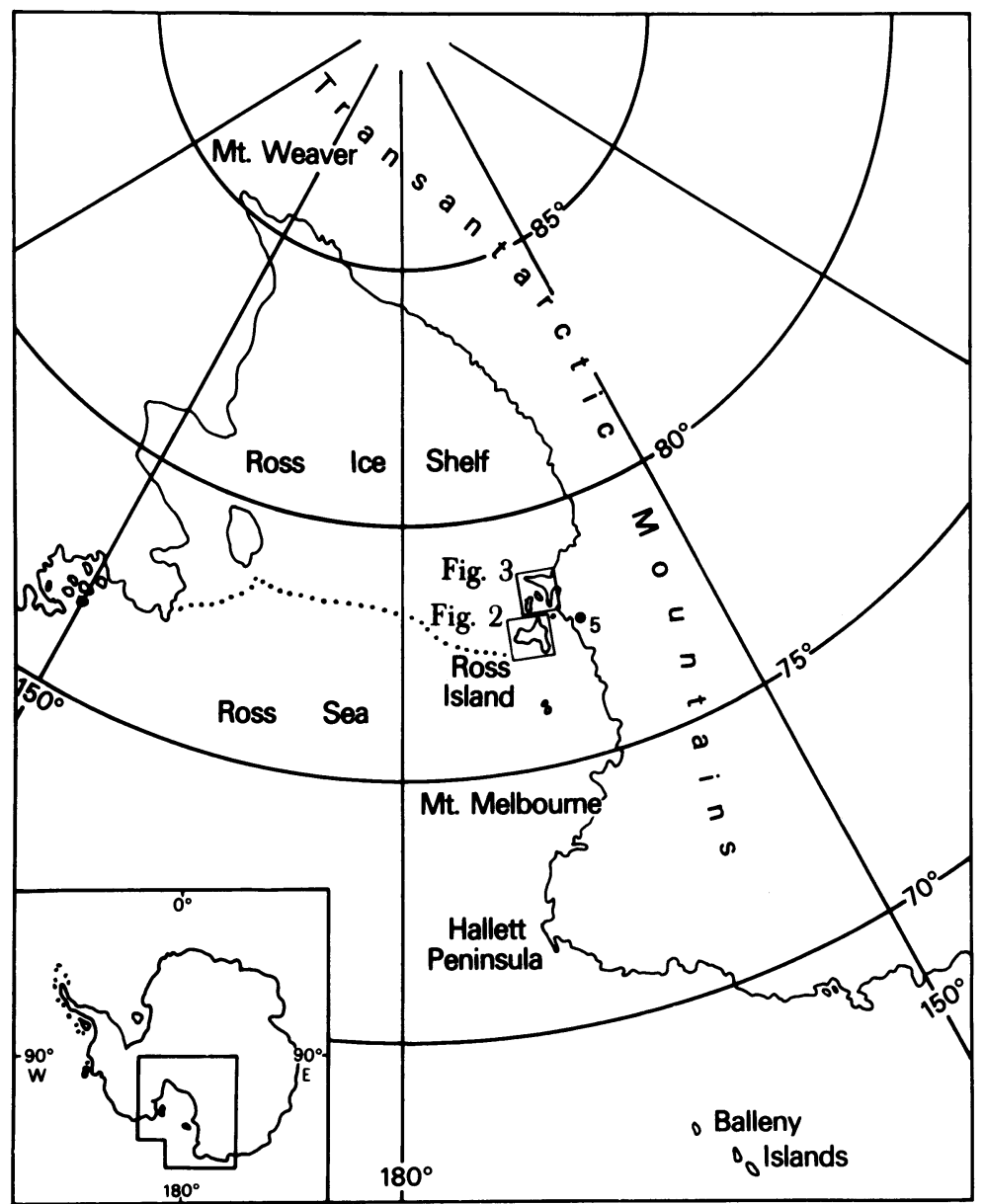

FIG. 1.-Index map of Antarctica showing location of Ross Island area (fig. 2), Mt. Discovery area (fig. 3), and sample no. 5 .

The Ross Sea petrologic province is characterized by alkalic, silica-undersaturated Neogene lavas and pyroclastic rocks. The volcanic rocks rest on older rocks of considerable diversity and range in age. These rocks include granite, gneiss, and metasedimentary rocks of late Precambrian and early Paleozoic age, the arenites of the Beacon Supergroup of Devonian to Jurassic age, and diabase sills of the Ferrar Dolerite, dated as Jurassic by McDougall (1963) and Compston et al. (1968).

Outcrops of these old rocks range from sea level to altitudes of 2,000 to $4,000 \mathrm{~m}$ in the Transantarctic Mountains, and xenoliths in the volcanic rocks of the Ross Island vicinity (Prior 1907; Thompson 1916; Forbes 1963) indicate that the Ross Sea region (fig. 1) is underlain by similar rocks. This interpretation is supported by aeromagnetic data (L. D. McGinnis, verbal communication, 1974). The large topographic relief on the western edge of the Ross Sea is interpreted as a zone of normal faulting or sharp flexures (Hamilton 1972).

The rock names used in this paper are based on modal compositions supplemented by chemical and normative data. 


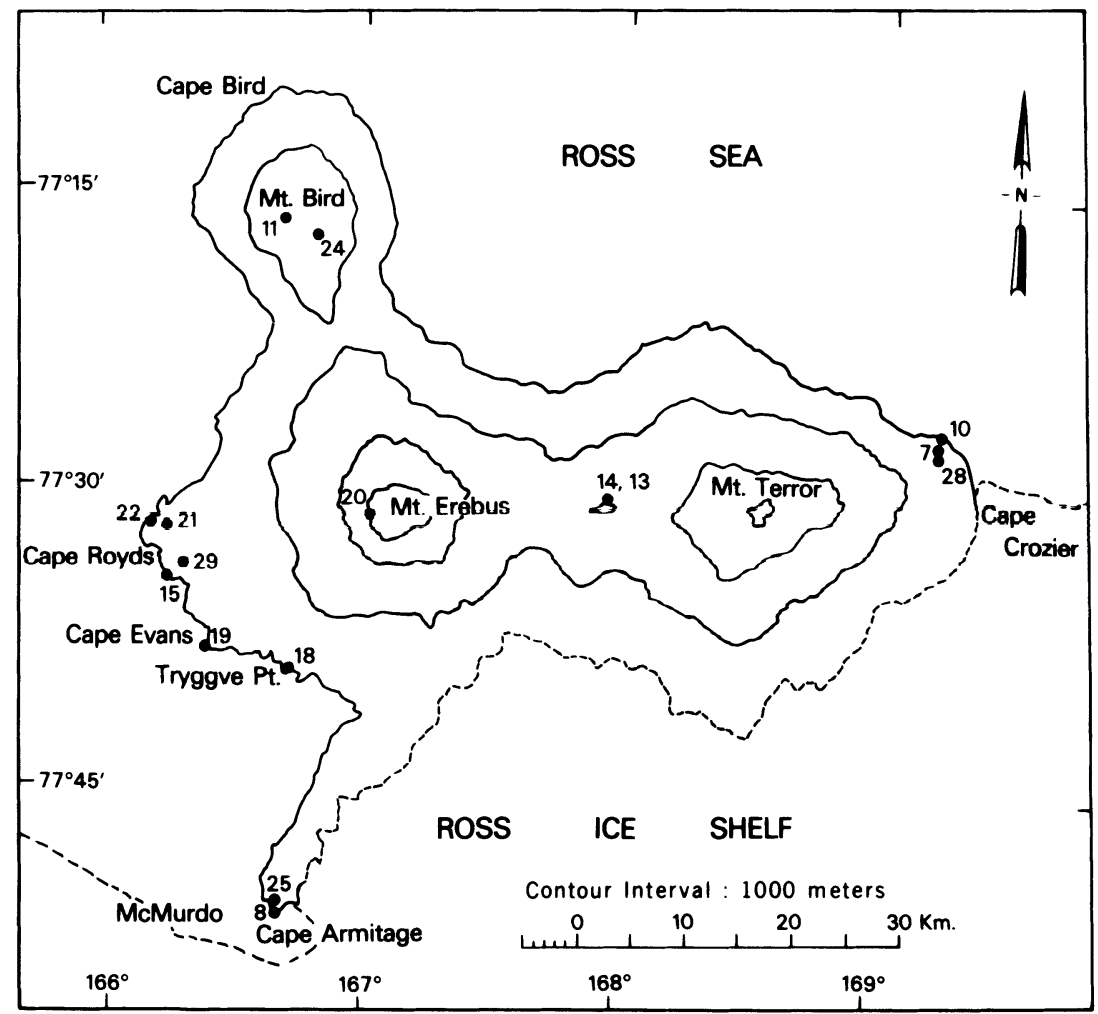

Frg. 2.-Map of Ross Island area showing locations of analyzed samples

At each of the major centers in the Ross Island vicinity there appears to be a succession that ranges from basanitoid to phonolite followed by younger basanitoids (Treves 1967). Pyroclastic deposits of tuff and breccia underlie the lavas as has been confirmed by the core from DVDP drill holes recently completed at McMurdo Station (locality 25, fig. 2).

\section{PRINCIPAL ROCK TYPES}

Basanitoid.-Basanitoids are alkalic olivine basalts which contain more than $5 \%$ normative nepheline, but no phenocrystic nepheline (Macdonald and Katsura 1964). With the exception of sample 12, which contains $3.7 \%$ of normative nepheline, the range is from 7.6 to $18 \%$, averaging $12 \%$ normative nepheline.

Basanitoids occur in nearly every exposure of volcanics in the Ross Island vicinity, and regardless of their relative ages, they are chemically and petrographically similar. All display textures from intersertal to granular, with augite, plagioclase, nepheline, and opaques forming the groundmass. Olivine and clinopyroxene are the dominant phenocrysts with most samples containing subhedral to euhedral olivine $\left(\mathrm{Fo}_{80}\right)$ and titaniferous augite. Less ubiquitous phenocrysts include plagioclase and kaersutite. Labradorite phenocrysts occur in only one of the analyzed basanitoids (sample 7) and are not abundant (less than $5 \%$ ) in other basanitoids in the Ross Island vicinity. They are generally anhedral and resorbed. Kaersutite in three of the analyzed basanitoids is generally subhedral to anhedral and rimmed with, or totally 


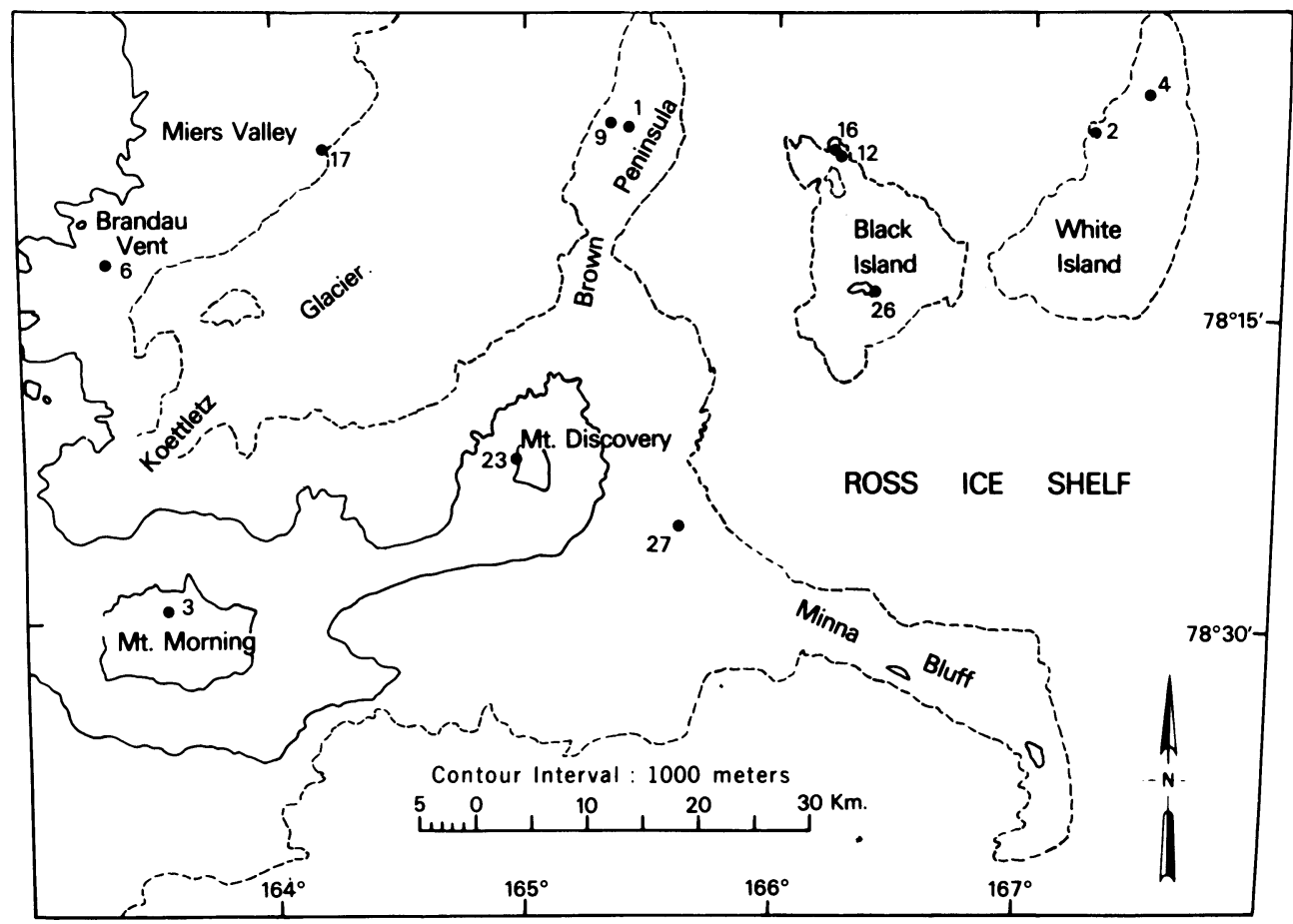

Fig. 3.-Map of Mt. Discovery area showing locations of analyzed samples

replaced by, opaque oxides. Sparse phenocrysts of opaque oxides occur in most of the samples.

Rocks of basanitoid composition occur both as thin flows and pyroclastic cones. The latter often contain ultramafic, mafic, and sedimentary rock inclusions from which small amounts of xenocrystic material, such as labradorite, appear to have been derived.

Trachybasalt.-The trachybasalts are rocks of intermediate composition, between basanitoid and phonolite. These rocks are fairly diverse in chemistry and mineralogy. They are characterized by pilotaxitic to trachytic texture and by plagioclase in the phenocryst assemblages. Like the basanitoids, the trachybasalts are undersaturated with respect to silica. Normative nepheline ranges from 6.3 to $15 \%$, averaging $11 \%$.

Plagioclase, kaersutite, and titaniferous augite are the dominant phenocrysts, each ranging from subhedral to euhedral. Plagioclase, commonly labradorite, makes up $4 \%-39 \%$ of each sample and is normally zoned with a range from $\mathrm{An}_{65}$ to $\mathrm{An}_{35}$. Kaersutite in the trachybasalts is not as strongly reacted as that in the basanitoids, but is commonly rimmed by opaque oxides. Accessory phenocrysts include olivine, opaque minerals, and trace amounts of apatite. The groundmass consists of plagioclase, augite, finely disseminated opaques, and, in some samples, a brown glass. At Half Moon Crater, $2 \mathrm{~km}$ north of McMurdo Station, a trachybasalt contains abundant mafic and sedimentary rock inclusions.

Anorthoclase phonolite.-Anorthoclase phonolites, or antarctic kenytes (Prior 1907; Smith 1954; Treves 1967), are remarkably uniform in chemistry and mineralogy. Flows crop out on the summit 
of Mt. Erebus and on the flanks of the mountain. All are coarsely porphyritic and contain $30 \%-40 \%$ subhedral to euhedral anorthoclase. The texture is trachytic; the groundmass consists of plagioclase, anorthoclase, apatite, opaque minerals, and nepheline. Normative nepheline ranges from $14 \%$ to $19 \%$ and averages $15 \%$.

Anorthoclase phenocrysts $\left(\mathrm{Or}_{16} \mathrm{Ab}_{63}\right.$ $\mathrm{An}_{21}$, Treves 1967) invariably contain inclusions of apatite, glass, augite, opaque materials, and olivine. In one sample with a holocrystalline groundmass, the crystal edges are slightly rounded, and the interior of the crystals exhibits mosaic intergrowths and polysynthetic and crosshatched twinning. Minor phenocrystic phases include augite, opaque minerals, apatite, and occasional olivine.

The anorthoclase phonolites range in age from at least $0.68 \pm 0.14 \mathrm{~m} . \mathrm{y}$. (Treves 1967) to present. During the 1972-1973 and 1973-1974 field seasons Mt. Erebus was active, and bombs which were collected on snow and ice at the summit consist of dark-brown glassy, pumiceous anorthoclase phonolite. The upper crater of Mt. Erebus is covered with loose crystals of anorthoclase, many longer than $5 \mathrm{~cm}$ which appear to be a lag deposit freed from the pumiceous matrix by weathering.

Mafic phonolites.-The mafic phonolites are quite variable both in amounts and proportions of phenocrysts and in chemistry. Normative nepheline ranges from $13 \%$ to $31 \%$ and averages $20 \%$. Most samples contain more augite and kaersutite than the anorthoclase phonolites, but plagioclase or anorthoclase may be the dominant phenocrysts. Locally, kaersutite is the dominant mafic phenocrysts in younger flows.

Mafic phonolites are ubiquitous in occurrence as small plugs and flows throughout the Ross Island vicinity. They often form prominent topographic features, such as Post Office Hill at Cape Crozier and Observation Hill near McMurdo Station. At most localities, domes intrude and flows overlie basanitoids and locally are partially mantled by younger basanitoids.

Trachyte.-The only analyzed sample which is oversaturated with respect to silica was collected at Mt. Cis between Cape Royds and Cape Evans (fig. 2, no. 29). Although earlier investigations described Mt. Cis as a parasitic cone which contains abundant inclusions (Thompson 1916), it appears to be a pingo which was pushed through the overlying anorthoclase phonolite (Treves 1967). Thompson (1916) and Jensen (1916) described the inclusions in the trachyte as sanidinites, pyroxene granulites, diabase, and metamorphosed sandstone. The abundant inclusions suggest the possibility that the composition of the Mt. Cis rock has been affected by contamination.

\section{ANALYTICAL DATA}

Slabs $1 \mathrm{~cm}$ thick were cut from the field samples with a diamond saw in water at the University of Nebraska and were used for the preparation of the rock powders at Northern Illinois University. Powder ground to pass an 80-mesh sieve was used for $\mathrm{FeO}$ which was determined titrimetrically with $\mathrm{KMnO}_{4}$. Powder ground to pass a 200-mesh sieve was used for all other determinations. Total water was determined by the Penfield method; $\mathrm{Na}_{2} \mathrm{O}$ and $\mathrm{K}_{2} \mathrm{O}$ by flame photometry; $\mathrm{P}_{2} \mathrm{O}_{5}$ by colorimetry; $\mathrm{SiO}_{2}, \mathrm{Al}_{2} \mathrm{O}_{3}, \mathrm{TiO}_{2}$, total Fe, $\mathrm{MnO}, \mathrm{CaO}, \mathrm{MgO}, \mathrm{Cu}, \mathrm{Zn}$, and $\mathrm{Rb}$ were all determined by atomic absorption spectrophotometry; and the remaining trace elements, by optical spectrography. The methods are essentially those described by Medlin et al. (1970) and Ingamells and Suhr (1963).

Bulk chemical analyses are given in tables 1-4. These include four conventional analyses made at Pennsylvania State University by J. B. Bodkin and J. C. DeVine (see nos. 7, 18, 20, and 21). $\mathrm{SiO}_{2}$ was determined gravimetrically on 11 of the 29 samples. Other check analyses at 


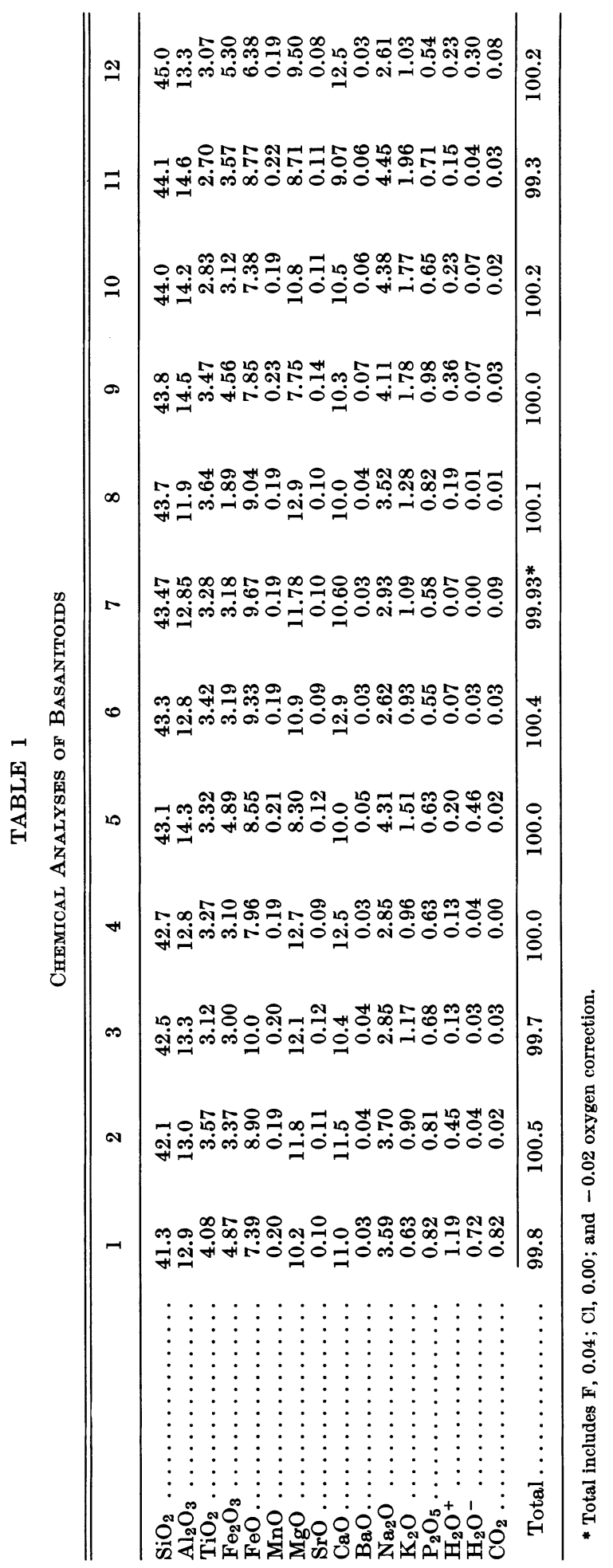


TABLE 2

Chemical Analyses of Trachybasalts

\begin{tabular}{|c|c|c|c|c|c|c|}
\hline & 13 & 14 & 15 & 16 & 17 & 18 \\
\hline $\mathrm{SiO}_{2} \ldots \ldots \ldots \ldots \ldots \ldots \ldots$ & 44.5 & 44.6 & 45.5 & 49.5 & 50.0 & 50.36 \\
\hline $\mathrm{Al}_{2} \mathrm{O}_{3} \ldots \ldots \ldots \ldots \ldots$ & 16.6 & 16.9 & 17.0 & 17.2 & 18.7 & 19.59 \\
\hline $\mathrm{TiO}_{2} \ldots \ldots \ldots \ldots \ldots$ & 3.91 & 3.46 & 3.11 & 2.64 & 2.36 & 1.93 \\
\hline $\mathrm{Fe}_{2} \mathrm{O}_{3} \ldots \ldots \ldots \ldots \ldots$ & 6.09 & 11.8 & 3.81 & 2.98 & 2.85 & 2.82 \\
\hline $\mathrm{FeO} \ldots \ldots \ldots \ldots \ldots \ldots$ & 6.01 & 0.09 & 8.41 & 6.38 & 5.42 & 5.16 \\
\hline MnO $\ldots \ldots \ldots \ldots \ldots \ldots$ & 0.25 & 0.22 & 0.24 & 0.21 & 0.20 & 0.20 \\
\hline $\mathrm{MgO} \ldots \ldots \ldots \ldots \ldots \ldots$ & 4.78 & 3.78 & 3.74 & 2.98 & 2.58 & 2.14 \\
\hline $\mathrm{SrO} \ldots \ldots \ldots \ldots \ldots \ldots \ldots$ & 0.15 & 0.15 & 0.14 & 0.12 & 0.15 & 0.14 \\
\hline $\mathrm{CaO} \ldots \ldots \ldots \ldots \ldots \ldots$ & 9.74 & 9.44 & 9.30 & 7.95 & 6.37 & 6.46 \\
\hline $\mathrm{BaO} \ldots \ldots \ldots \ldots \ldots \ldots$ & 0.07 & 0.07 & 0.06 & 0.08 & 0.07 & 0.09 \\
\hline $\mathrm{Na}_{2} \mathrm{O} \ldots \ldots \ldots \ldots \ldots \ldots$ & 4.35 & 5.37 & 5.07 & 5.02 & 6.35 & 6.57 \\
\hline $\mathbf{K}_{2} \mathrm{O} \ldots \ldots \ldots \ldots \ldots \ldots$ & 1.92 & 2.01 & 2.13 & 2.57 & 3.43 & 3.32 \\
\hline $\mathrm{P}_{2} \mathrm{O}_{5} \ldots \ldots \ldots \ldots \ldots \ldots$ & 1.53 & 1.39 & 1.56 & 1.08 & 0.99 & 0.85 \\
\hline $\mathrm{H}_{2} \mathrm{O}^{+} \ldots \ldots \ldots \ldots \ldots$ & 0.20 & 0.14 & 0.26 & 0.73 & 0.21 & 0.23 \\
\hline $\mathrm{H}_{2} \mathrm{O}^{-} \ldots \ldots \ldots \ldots \ldots$ & 0.06 & 0.06 & 0.10 & 0.14 & 0.15 & 0.03 \\
\hline $\mathrm{CO}_{2} \ldots \ldots \ldots \ldots \ldots \ldots \ldots$ & 0.03 & 0.02 & 0.01 & 0.02 & 0.03 & 0.07 \\
\hline Total $\ldots \ldots \ldots \ldots \ldots$ & 100.2 & 99.5 & 100.4 & 99.6 & 99.9 & $100.09 *$ \\
\hline
\end{tabular}

* Total includes F, $0.14 ; \mathrm{Cl}, 0.06$; and -0.07 oxygen correction.

Northern Illinois University included $\mathrm{TiO}_{2}$ and $\mathrm{MnO}$, colorimetrically; $\mathrm{FeO}$ and total Fe, volumetrically; $\mathrm{P}_{2} \mathrm{O}_{5}$ and $\mathrm{H}_{2} \mathrm{O}$, gravimetrically; and $\mathrm{Na}_{2} \mathrm{O}$ and $\mathrm{K}_{2} \mathrm{O}$, photometrically. As a result of these determinations, many of the atomic absorption analyses were repeated. The final analyses represent a combination of methods and have a precision and accuracy approaching that of conventional rock analyses.

The relative errors in the trace-element determinations (tables 5-8) are large compared to the major constituents and are difficult to assess. $\mathrm{Rb}$ and $\mathrm{Sr}$ were determined by isotope dilution on a composite of basanitoid samples (nos. 1-11) and the results are compared in table 9 with the averages calculated from the values in table 5. The isotope-dilution value for $\mathrm{Rb}$ is much less $(\sim 25 \%)$ and for $\mathrm{Sr}$ is greater $(\sim 7 \%)$ than the averages which represent atomic absorption and emission spectrographic data for $\mathrm{Rb}$ and for $\mathrm{Sr}$, respectively. Individual determinations may have larger errors than those indicated by the averages. In contrast with the results for $\mathrm{Rb}$ and $\mathrm{Sr}$, determinations of $\mathrm{Na}_{2} \mathrm{O}$ and $\mathrm{K}_{2} \mathrm{O}$ on the composite sample (table 9) are in good agreement with the calculated averages.

Major elements.-The samples are very fresh, and with two exceptions the contents of $\mathrm{H}_{2} \mathrm{O}^{+}$(above $110^{\circ} \mathrm{C}$ ), $\mathrm{H}_{2} \mathrm{O}^{-}$ (below $110^{\circ} \mathrm{C}$ ), and $\mathrm{CO}_{2}$ are uniformly low. The exceptions are a basanitoid (table 1, no. 1) from Brown Peninsula (fig. 3) and the trachyte from Mt. Cis (table 4, no. 29; fig. 2).

The basanitoids (table 1) are characterized by $\mathrm{SiO}_{2}$ contents of less than $45 \%$, high $\mathrm{TiO}_{2}, \mathrm{CaO}$, and $\mathrm{MgO}$, and a range from $0.6 \%$ to $2.0 \%$ in $\mathrm{K}_{2} \mathrm{O}$. An average of the 12 analyses is given in table 10 (no. 30 ). The trachybasalts (table 2) are considerably enriched in $\mathrm{Na}_{2} \mathrm{O}, \mathrm{K}_{2} \mathrm{O}$, $\mathrm{P}_{2} \mathrm{O}_{5}$, and $\mathrm{Al}_{2} \mathrm{O}_{3}$ and are strongly depleted in $\mathrm{MgO}$ relative to the basanitoids. The trachybasalts may be further divided into low-silica and high-silica groups (table 10, nos. 31 and 32). $\mathrm{TiO}_{2}, \mathrm{P}_{2} \mathrm{O}_{5}$, and $\mathrm{MnO}$ are markedly enriched in the low-silica trachybasalt relative to the high-silica group.

Four analyses of anorthoclase phonolite (table 3) are similar, and an average is given in table 10 (no. 33). The mafic phonolites (table 4) show a range in 
TABLE 3

Chemical Analyses of Anorthoclase Phonolites

\begin{tabular}{|c|c|c|c|c|}
\hline 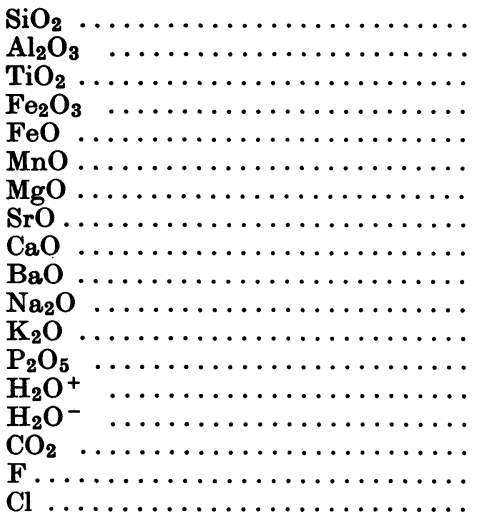 & $\begin{array}{l}55.1 \\
19.5 \\
1.04 \\
1.91 \\
4.12 \\
0.21 \\
1.13 \\
0.11 \\
3.30 \\
0.12 \\
8.03 \\
4.68 \\
0.42 \\
0.22 \\
0.17 \\
\text { 0.01 } \\
\text { n.d. } \\
\text { n.d. }\end{array}$ & $\begin{array}{r}55.71 \\
18.14 \\
1.22 \\
1.83 \\
4.90 \\
0.25 \\
1.37 \\
0.10 \\
3.35 \\
0.13 \\
7.92 \\
4.35 \\
0.49 \\
0.11 \\
0.00 \\
0.03 \\
0.15 \\
0.09\end{array}$ & $\begin{array}{r}56.10 \\
19.57 \\
1.10 \\
1.78 \\
3.46 \\
0.19 \\
1.19 \\
0.11 \\
3.24 \\
0.12 \\
7.80 \\
4.26 \\
0.45 \\
0.30 \\
0.14 \\
0.07 \\
0.09 \\
0.06\end{array}$ & $\begin{array}{c}56.2 \\
19.9 \\
1.01 \\
1.91 \\
3.59 \\
0.19 \\
1.16 \\
0.10 \\
3.32 \\
0.12 \\
7.89 \\
4.24 \\
0.46 \\
0.13 \\
0.06 \\
0.02 \\
\text { n.d. } \\
\text { n.d. }\end{array}$ \\
\hline Total $\ldots \ldots \ldots \ldots \ldots$ & 100.1 & 100.14 & 100.03 & 100.3 \\
\hline$-0 \ldots \ldots \ldots \ldots \ldots \ldots$ & & 0.08 & 0.05 & \\
\hline Total $\ldots \ldots \ldots \ldots \ldots \ldots$ & & 100.06 & 99.98 & \\
\hline
\end{tabular}

TABLE 4

Chemical Analyses of Phonolites and Trachyte

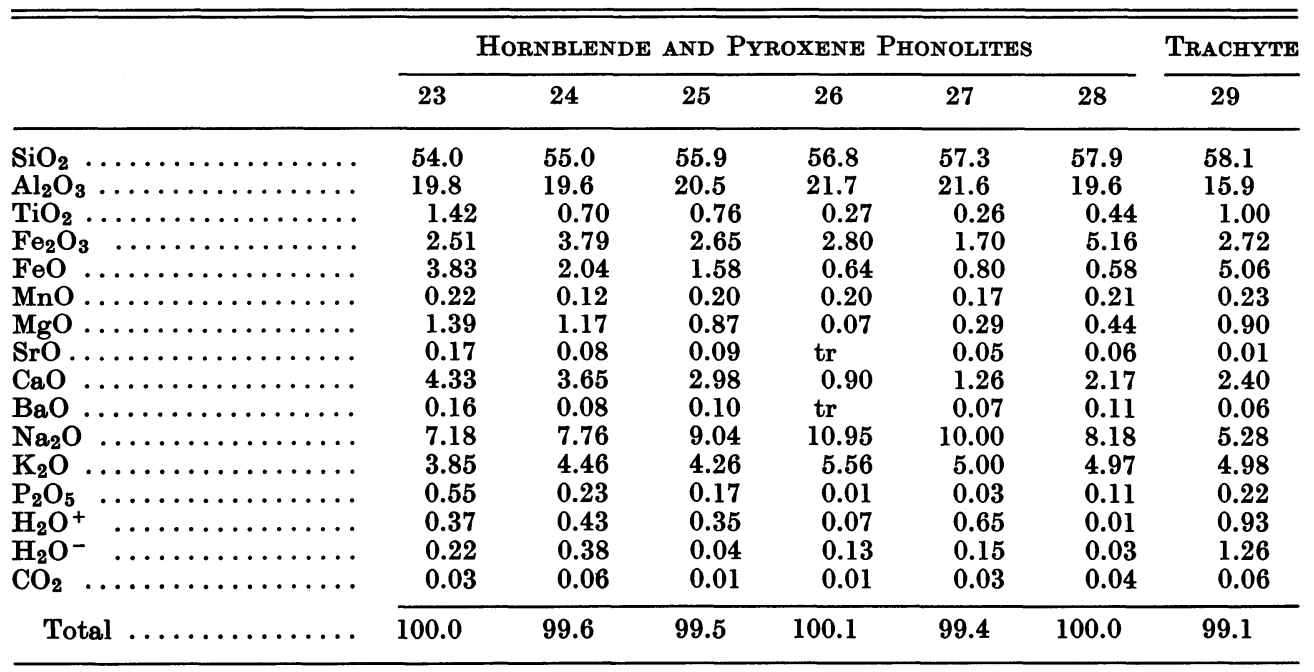




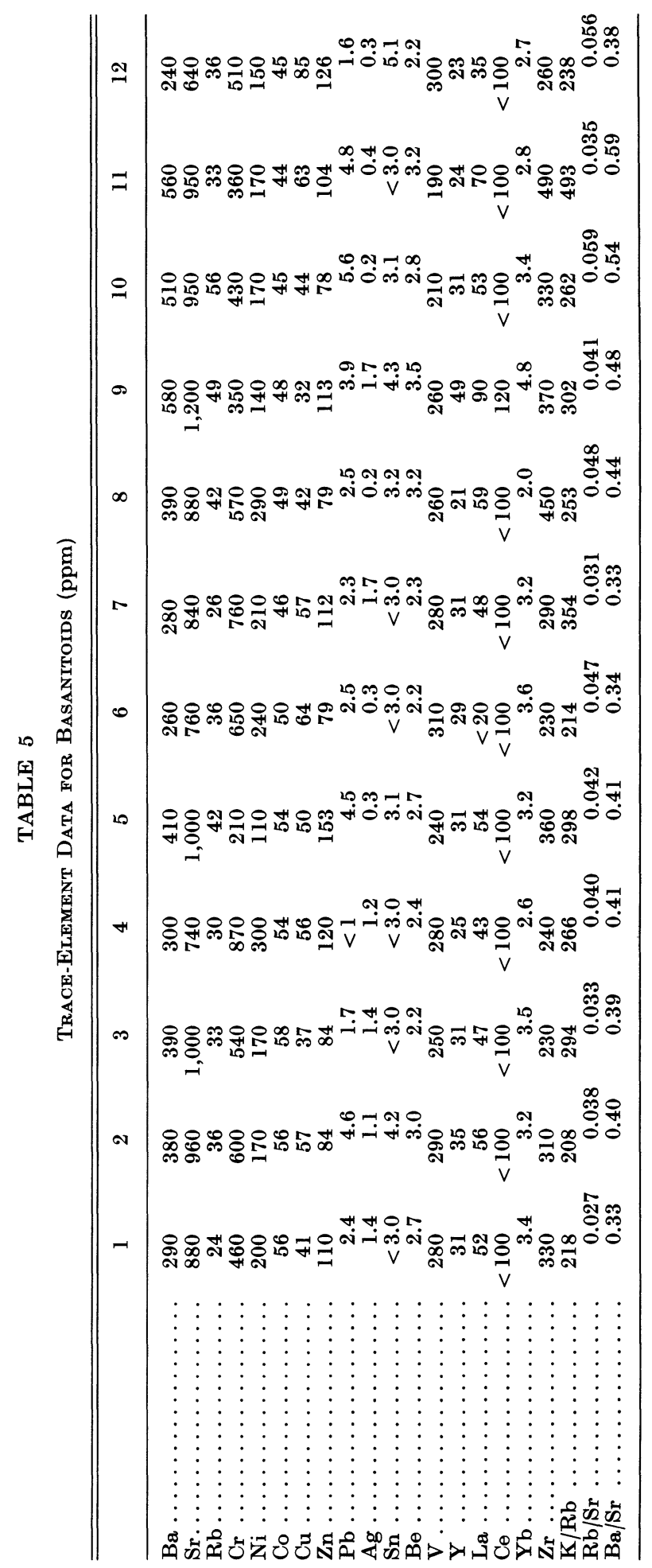


TABLE 6

Trace-Element Data for Trachybasalts (ppm)

\begin{tabular}{|c|c|c|c|c|c|c|}
\hline & 13 & 14 & 15 & 16 & 17 & 18 \\
\hline Ва......... & 630 & 630 & 510 & 710 & 660 & 760 \\
\hline Sr $\ldots \ldots \ldots \ldots \ldots \ldots \ldots$ & 1,270 & 1,270 & 1,200 & 1,000 & 1,270 & 1,180 \\
\hline $\mathrm{Rb} \ldots \ldots \ldots \ldots \ldots \ldots$ & 50 & 60 & 56 & 54 & 72 & 68 \\
\hline $\mathrm{Cr} \ldots \ldots \ldots \ldots \ldots \ldots$ & $<5$ & $<5$ & $<5$ & $<5$ & $<5$ & $<5$ \\
\hline $\mathrm{Ni}, \ldots \ldots \ldots \ldots \ldots \ldots \ldots$ & 14 & $<10$ & $<10$ & $<10$ & $<10$ & $<10$ \\
\hline Co $\ldots \ldots \ldots \ldots \ldots \ldots$. & 32 & 26 & 22 & $<10$ & 15 & $<10$ \\
\hline $\mathrm{Cu} \ldots \ldots \ldots \ldots \ldots \ldots \ldots$ & 34 & 25 & 17 & 36 & 32 & 12 \\
\hline $\mathrm{Zn} \ldots \ldots \ldots \ldots \ldots \ldots \ldots$ & 109 & 111 & 115 & 95 & 91 & 89 \\
\hline $\mathrm{Pb} \ldots \ldots \ldots \ldots \ldots \ldots \ldots$ & 5.1 & 3.5 & 5.0 & 7.6 & 4.4 & 5.2 \\
\hline $\mathrm{Ag} \ldots \ldots \ldots \ldots \ldots \ldots$ & 0.7 & 0.3 & 0.3 & 0.3 & $<0.1$ & $<0.1$ \\
\hline $\operatorname{sn} \ldots \ldots \ldots \ldots \ldots \ldots$ & $<2.5$ & $<2.5$ & $<2.5$ & $<2.5$ & 5.1 & 3.5 \\
\hline $\mathrm{Be} \ldots \ldots \ldots \ldots \ldots \ldots$ & 3.5 & 3.3 & 3.2 & 3.1 & 4.2 & 4.1 \\
\hline $\mathrm{V} \ldots \ldots \ldots \ldots \ldots \ldots$ & 190 & 120 & 130 & 130 & 72 & 39 \\
\hline $\mathbf{Y} \ldots \ldots \ldots \ldots \ldots$ & 37 & 33 & 41 & 37 & 43 & 37 \\
\hline 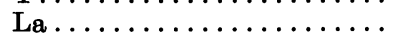 & 80 & 86 & 80 & 72 & 92 & 94 \\
\hline $\mathrm{Ce} \ldots \ldots \ldots \ldots \ldots \ldots$ & $<100$ & 100 & 110 & 100 & 130 & 130 \\
\hline $\mathrm{Yb} \ldots \ldots \ldots \ldots \ldots \ldots$ & 3.6 & 2.9 & 4.6 & 3.7 & 3.6 & 3.2 \\
\hline $\mathbf{Z} \mathbf{r} \ldots \ldots \ldots \ldots \ldots \ldots$ & 340 & 410 & 390 & 400 & 490 & 470 \\
\hline K/Rb $\ldots \ldots \ldots \ldots \ldots \ldots$ & 319 & 278 & 316 & 395 & 395 & 408 \\
\hline $\mathrm{Rb} / \mathrm{Sr} \ldots \ldots \ldots \ldots \ldots \ldots$ & 0.039 & 0.047 & 0.047 & 0.054 & 0.057 & 0.058 \\
\hline $\mathrm{Ba} / \mathrm{Sr} \ldots \ldots \ldots \ldots \ldots \ldots$ & 0.50 & 0.50 & 0.43 & 0.71 & 0.52 & 0.64 \\
\hline
\end{tabular}

TABLE 7

Trace-Element Data for Anorthoclase Phonolites (ppm)

\begin{tabular}{|c|c|c|c|c|}
\hline & 19 & 20 & 21 & 22 \\
\hline 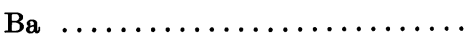 & 1,070 & 1,200 & 1,070 & 1,070 \\
\hline 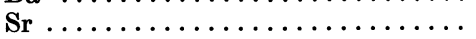 & 930 & 840 & 950 & 900 \\
\hline 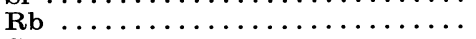 & 97 & 80 & 87 & 91 \\
\hline 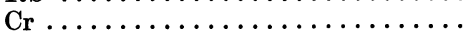 & $<5$ & $<5$ & $<5$ & $<5$ \\
\hline 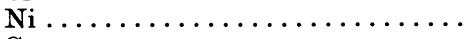 & $<10$ & 13 & $<10$ & $<10$ \\
\hline 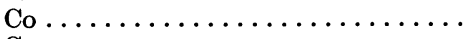 & $<10$ & $<10$ & $<10$ & $<10$ \\
\hline $\mathrm{Cu} \ldots \ldots \ldots \ldots \ldots \ldots \ldots \ldots \ldots$ & 39 & 24 & 19 & 20 \\
\hline $\mathrm{Z}_{n} \ldots \ldots \ldots \ldots \ldots \ldots \ldots \ldots \ldots$ & 118 & 135 & 99 & 98 \\
\hline $\mathbf{P b} \ldots \ldots \ldots \ldots \ldots \ldots \ldots \ldots \ldots \ldots \ldots \ldots$ & 5.0 & 3.3 & 5.3 & 6.4 \\
\hline $\mathrm{Ag}, \ldots \ldots \ldots \ldots \ldots \ldots \ldots \ldots \ldots$ & 0.1 & 0.5 & 0.4 & 15 \\
\hline 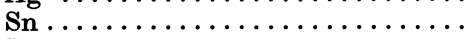 & 6.0 & 3.3 & 4.2 & 7.2 \\
\hline $\mathrm{B} \boldsymbol{\ldots} \ldots \ldots \ldots \ldots \ldots \ldots \ldots \ldots \ldots \ldots$ & 6.2 & 6.2 & 5.8 & 6.2 \\
\hline 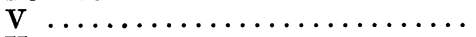 & $<10$ & 32 & 16 & 16 \\
\hline 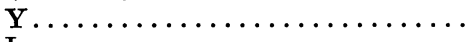 & 61 & 66 & 46 & 55 \\
\hline 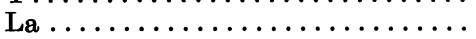 & 120 & 140 & 110 & 120 \\
\hline 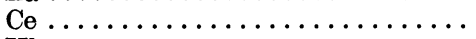 & 220 & 240 & 200 & 230 \\
\hline 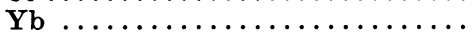 & 5.0 & 5.6 & 4.1 & 4.9 \\
\hline $\mathbf{Z} \mathbf{r} \ldots \ldots \ldots \ldots \ldots \ldots \ldots \ldots \ldots \ldots$ & 640 & 540 & 570 & 590 \\
\hline $\mathbf{K} / \mathbf{R b} \ldots \ldots \ldots \ldots \ldots \ldots \ldots$ & 365 & 431 & 379 & 387 \\
\hline $\mathrm{Rb} / \mathrm{Sr} \ldots \ldots \ldots \ldots \ldots \ldots \ldots \ldots$ & 0.10 & 0.095 & 0.092 & 0.10 \\
\hline 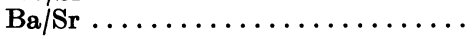 & 1.15 & 1.43 & 1.13 & 1.19 \\
\hline
\end{tabular}


TABLE 8

Trace-Element Data for Phonolites and Trachyte (ppm)

\begin{tabular}{|c|c|c|c|c|c|c|c|}
\hline & \multicolumn{6}{|c|}{ Hornblende and Pyroxene Phonolites } & \multirow{2}{*}{$\frac{\text { TRACHYTE }}{29}$} \\
\hline & 23 & 24 & 25 & 26 & 27 & 28 & \\
\hline$\ldots \ldots \ldots \ldots \ldots \ldots$, & 1,430 & 750 & 860 & $\sim 15$ & 580 & 990 & 520 \\
\hline $\mathrm{Sr} \ldots \ldots \ldots \ldots \ldots$ & 1,440 & 640 & 780 & $<\mathbf{3 0}$ & 420 & 520 & 48 \\
\hline $\mathrm{Rb} \ldots \ldots \ldots \ldots \ldots$ & 68 & 112 & 137 & 156 & 173 & 125 & 104 \\
\hline $\mathbf{C r} \ldots \ldots \ldots \ldots \ldots \ldots$ & $<5$ & 10 & 10 & $<5$ & $<5$ & $<5$ & $<5$ \\
\hline $\mathrm{Ni} \ldots \ldots \ldots \ldots \ldots \ldots$ & $<10$ & 12 & 12 & 25 & $<10$ & $<10$ & $<10$ \\
\hline Co $\ldots \ldots \ldots \ldots \ldots \ldots$ & $<10$ & $<10$ & $<10$ & $<10$ & $<10$ & $<10$ & $<10$ \\
\hline $\mathrm{Cu} \ldots \ldots \ldots \ldots \ldots \ldots$ & 8 & 30 & 34 & 24 & 19 & 25 & 28 \\
\hline $\mathrm{Zn} \ldots \ldots \ldots \ldots \ldots$ & 87 & 124 & 108 & 120 & 98 & 111 & 174 \\
\hline $\mathrm{Pb} \ldots \ldots \ldots \ldots \ldots \ldots$ & 4.9 & 11 & 13 & 15 & 16 & 6.6 & 11 \\
\hline $\mathrm{Ag}, \ldots \ldots \ldots \ldots \ldots \ldots$ & 0.4 & $<0.1$ & 1.8 & 7.4 & $<0.1$ & 0.9 & 0.1 \\
\hline Sn $\ldots \ldots \ldots \ldots \ldots \ldots$ & $<3.0$ & 6.1 & $<3.0$ & 6.2 & 3.0 & 6.5 & 6.2 \\
\hline $\operatorname{Be} \ldots \ldots \ldots \ldots \ldots$ & 4.4 & 6.1 & 7.4 & 8.8 & 9.4 & 5.3 & 6.4 \\
\hline $\mathbf{V} \ldots \ldots \ldots \ldots \ldots$ & 16 & 43 & 48 & $<10$ & $<10$ & $<10$ & $<10$ \\
\hline $\mathbf{Y} \ldots \ldots \ldots \ldots \ldots \ldots$ & 46 & 37 & 31 & 43 & 39 & 26 & 74 \\
\hline La $\ldots \ldots \ldots \ldots \ldots$ & 120 & 130 & 140 & 180 & 120 & 150 & 150 \\
\hline $\mathrm{Ce} \ldots \ldots \ldots \ldots \ldots$ & 210 & 260 & 250 & 300 & 200 & 240 & 290 \\
\hline $\mathrm{Yb} \ldots \ldots \ldots \ldots \ldots \ldots$ & 3.7 & 3.3 & 3.2 & 4.3 & 3.0 & 3.1 & 7.1 \\
\hline $\mathbf{Z} \mathbf{r} \ldots \ldots \ldots \ldots \ldots \ldots$ & 510 & 960 & 1,200 & 620 & 510 & 580 & 620 \\
\hline $\mathrm{K} / \mathrm{Rb} \ldots \ldots \ldots \ldots$ & 470 & 311 & 258 & 296 & 227 & 330 & 398 \\
\hline $\mathrm{Rb} / \mathrm{Sr} \ldots \ldots \ldots \ldots \ldots$ & 0.047 & 0.18 & 0.18 & $\ldots$ & 0.41 & 0.24 & 2.1 \\
\hline $\mathrm{Ba} / \mathrm{Sr} \ldots \ldots \ldots \ldots$ & 0.99 & 1.17 & 1.10 & $\ldots$ & 1.38 & 1.90 & 10.8 \\
\hline
\end{tabular}

TABLE 9

Comparative Data Calculated from Individual Analyses and Determined on a Composite of the Basanitoid Samples

\begin{tabular}{lcc}
\hline \hline & Calculated & Determined \\
\hline $\mathrm{Na}_{2} \mathrm{O}(\mathrm{wt} \%) \ldots$ & 3.57 & $3.55^{*}$ \\
$\mathrm{~K}_{2} \mathrm{O}(\mathrm{wt} \%) \ldots$ & 1.27 & $1.27^{*}$ \\
$\mathrm{Rb}(\mathrm{ppm}) \ldots \ldots$ & 37 & $30 \dagger$ \\
$\mathrm{Sr}(\mathrm{ppm}) \ldots \ldots$ & 925 & $993 \dagger$ \\
\hline
\end{tabular}

* Flame photometry (SSG).

$\dagger$ Isotope dilution (C. E. Hedge).

composition; hence, the average (table 10, no. 34) must be used with caution. These rocks range from $\mathbf{5 4} \%$ to $\mathbf{5 8} \%$ in $\mathrm{SiO}_{2}$, from $7.0 \%$ to $11 \%$ in $\mathrm{Na}_{2} \mathrm{O}$, and from $3.8 \%$ to $5.6 \%$ in $\mathrm{K}_{2} \mathrm{O}$.

The variations of the major constituents with $\mathrm{SiO}_{2}$ are shown in figure 4. The distribution is bimodal with the gap between $46 \%$ and $54 \% \mathrm{SiO}_{2}$ occupied by the high-silica trachybasalts. If the older published analyses from the area are included, a few additional points fall in the intermediate range. The trends, however, are not altered; the distribution remains bimodal; and the scatter of points is considerably increased as should be expected from chemical analyses made at different times in different laboratories.

Data from published analyses (Prior 1902, 1907; Jensen 1916; Smith 1954; Forbes and Kuno 1965; Boudette and Ford 1966; Cole and Ewart 1968; McIver and Gevers 1970) are included with the new data in figure 5 in which the mole proportions, $\mathrm{CaO}: \mathrm{Na}_{2} \mathrm{O}: \mathrm{K}_{2} \mathrm{O}$, are plotted. The trend is essentially linear with the ratio $\mathrm{Na}_{2} \mathrm{O}$ : $\mathrm{K}_{2} \mathrm{O}$ nearly constant. The trachyte from Mt. Cis, however, plots well above the trend, and its position is confirmed by an earlier analysis.

The high contents of $\mathrm{Na}_{2} \mathrm{O}, \mathrm{K}_{2} \mathrm{O}, \mathrm{TiO}_{2}$, and $\mathrm{P}_{2} \mathrm{O}_{5}$ characterize the alkali basalts. Of these the behavior of $\mathrm{P}_{2} \mathrm{O}_{5}$ is difficult to explain. In figure 4 the points for $\mathrm{P}_{2} \mathrm{O}_{5}$ in the basanitoids form a separate group, a pattern not shown by any other major constituent. In a plot of $\mathrm{P}_{2} \mathrm{O}_{5}$ against $\mathrm{TiO}_{2}$ 

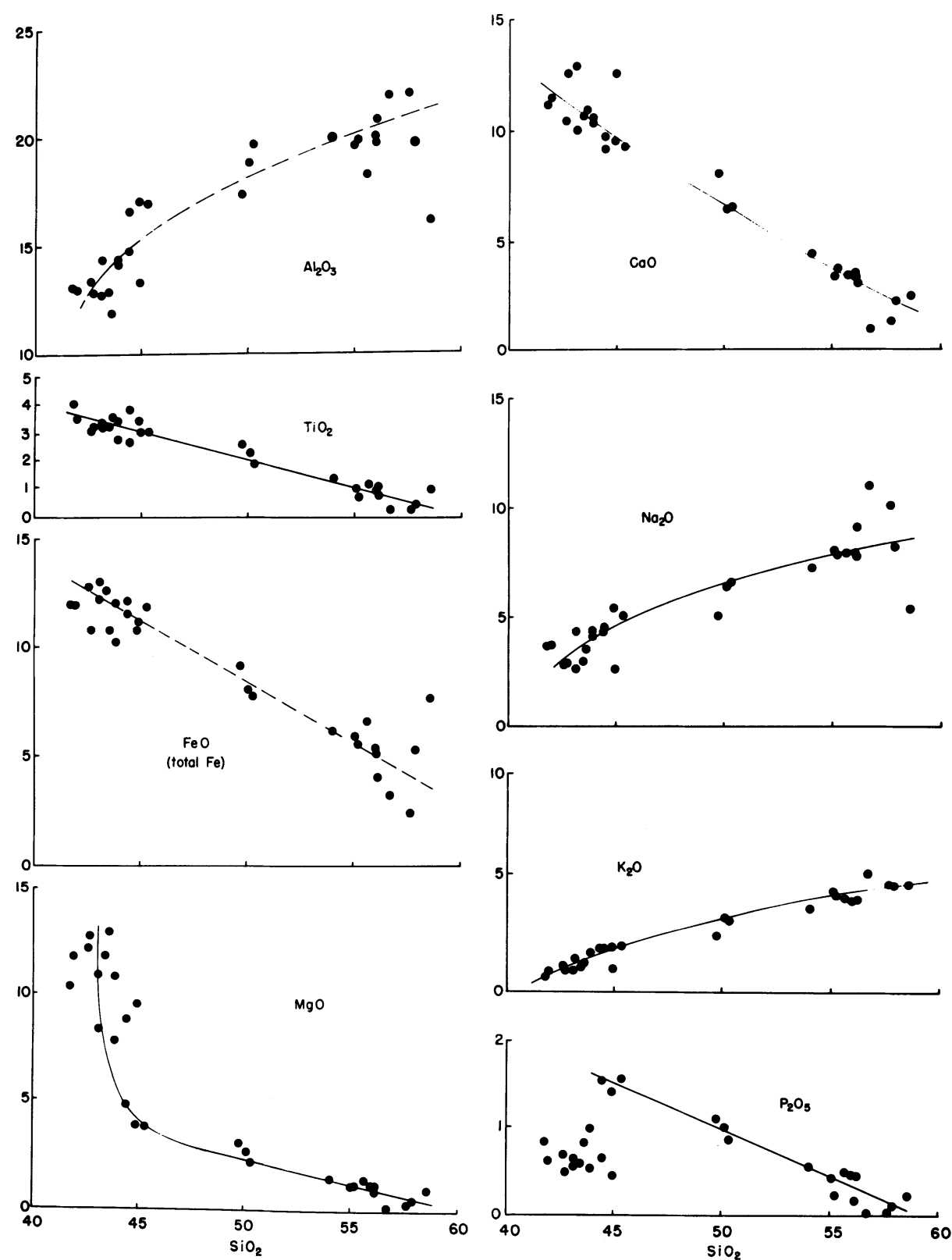

Frg. 4.-Variations of major constituents with $\mathrm{SiO}_{2}$

(fig. 6), the basanitoid samples again fall in a separate group. Normative apatite ranges from $1.3 \%$ to $2.3 \%$, averaging $1.7 \%$ in the basanitoids, but in the low-silica trachybasalt the average normative apatite is $3.7 \%$.
Trace elements.-Although the errors in the determinations of the trace elements are large compared to the major constituents, the trends shown in figures 7-10 are real. La and $\mathrm{Zr}$ show essentially linear variations with $\mathrm{Na}$ (fig. 7). Plots of $\mathrm{Yb}$ and 


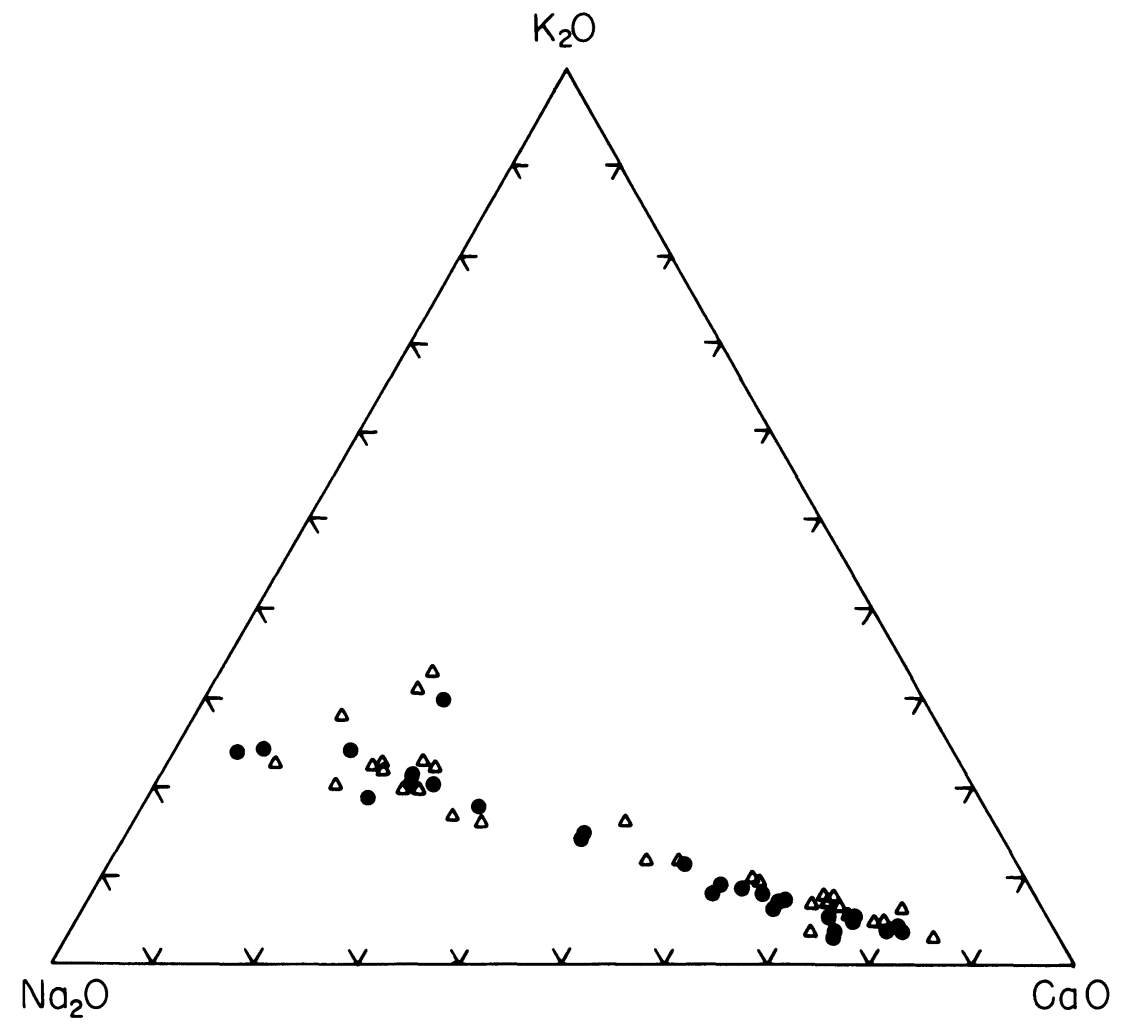

FIG. 5.- $\mathrm{CaO}: \mathrm{Na}_{2} \mathrm{O}: \mathrm{K}_{2} \mathrm{O}$ diagram (mole ratios) for volcanic rocks of Ross Island vicinity. Filled circles, new analyses; triangles, old analyses from literature.

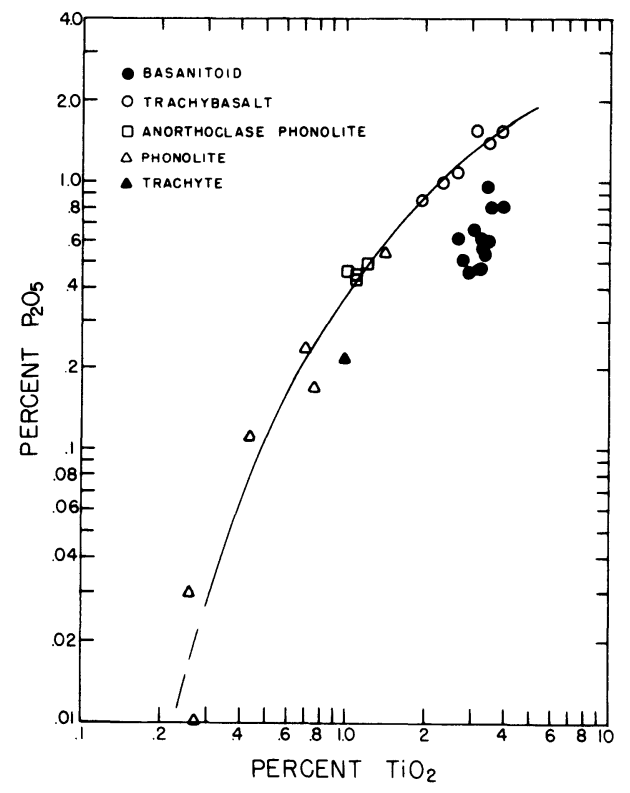

FIG. 6.-Variations of $\mathrm{P}_{2} \mathrm{O}_{5}$ with $\mathrm{TiO}_{2}$
$\mathrm{Y}$ would show a similar correlation, but the scatter of the points is much greater than for La. In large part, this must be attributed to analytical error. The average La content of the basanitoids is approximately $50 \mathrm{ppm}$, and $\mathrm{La} / \mathrm{Yb}$ is about 20 . For the mafic phonolites (table 8), the average La content is approximately 140 $\mathrm{ppm}$, and $\mathrm{La} / \mathrm{Yb}$ is approximately 40 . Results from isotope-dilution analyses (Kay and Gast 1973) for similar rock types are of the same order of magnitude.

The variations of $\mathrm{Pb}$ and $\mathrm{Rb}$ with $\mathrm{K}$ (fig. 8) are similar, and the relatively greater scatter in the $\mathrm{Pb}$ data is largely analytical error. $\mathrm{Rb}$ increases with $\mathrm{K}$ content in the basanitoids and trachybasalts, but shows a marked increase in rate of growth in the phonolitic rocks. Like $\mathrm{Pb}$ and $\mathrm{Rb}, \mathrm{Ba}$ and Sr vary with $\mathrm{K}$ (fig. 9) along two distinct trends. Both $\mathrm{Ba}$ and $\mathrm{Sr}$ increase with $\mathrm{K}$ content in the basanitoids 


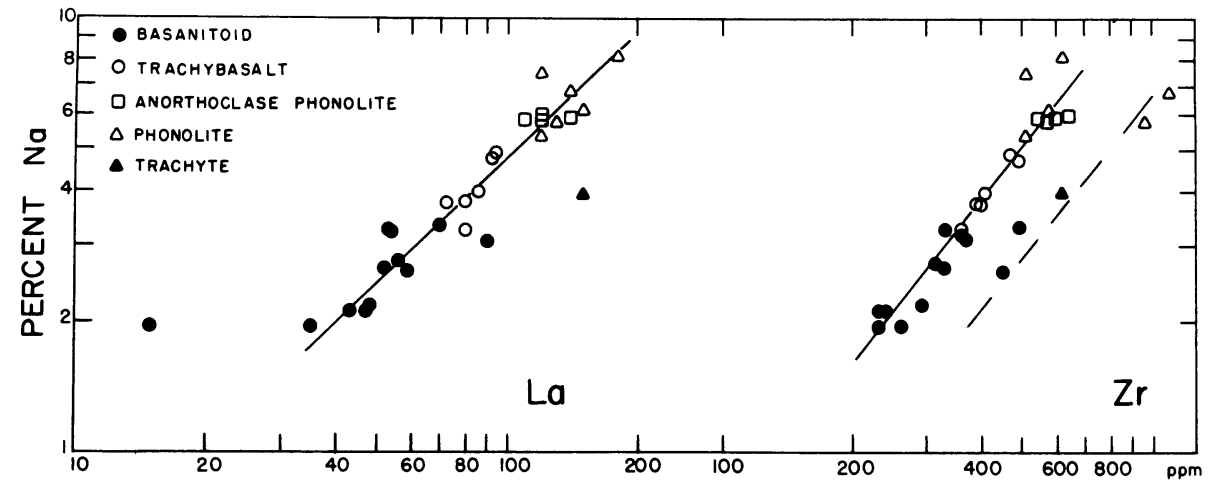

FIG. 7.-Variations of $\mathrm{La}$ and $\mathrm{Zr}$ with $\mathrm{Na}$

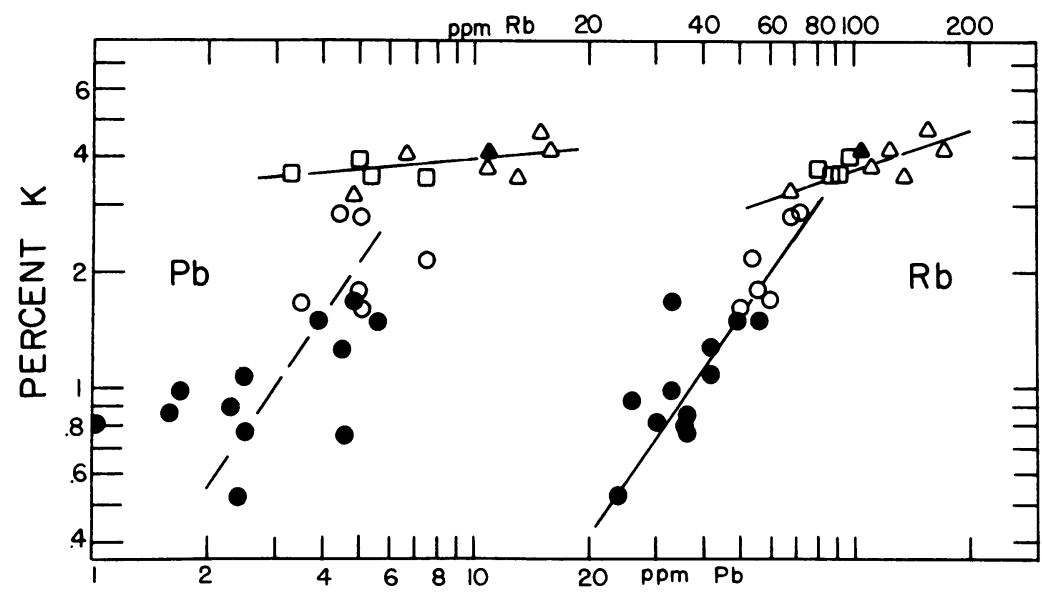

Fig. 8.-Variations of $\mathrm{Pb}$ and $\mathrm{Rb}$ with $\mathrm{K}$

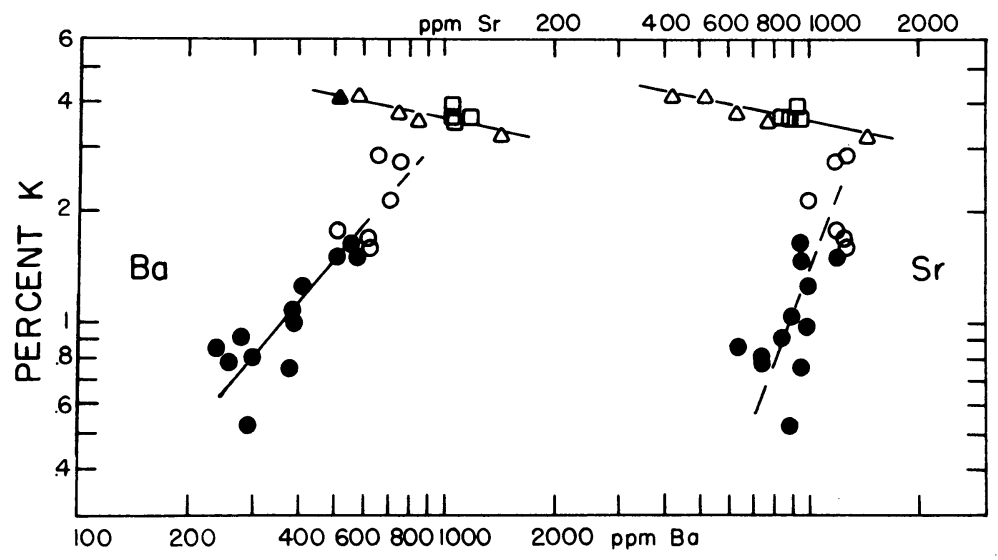

Fig. 9.-Variations of $\mathrm{Ba}$ and $\mathrm{Sr}$ with $\mathrm{K}$ 
TABLE 10

Average Chemical Composition of Rock Types

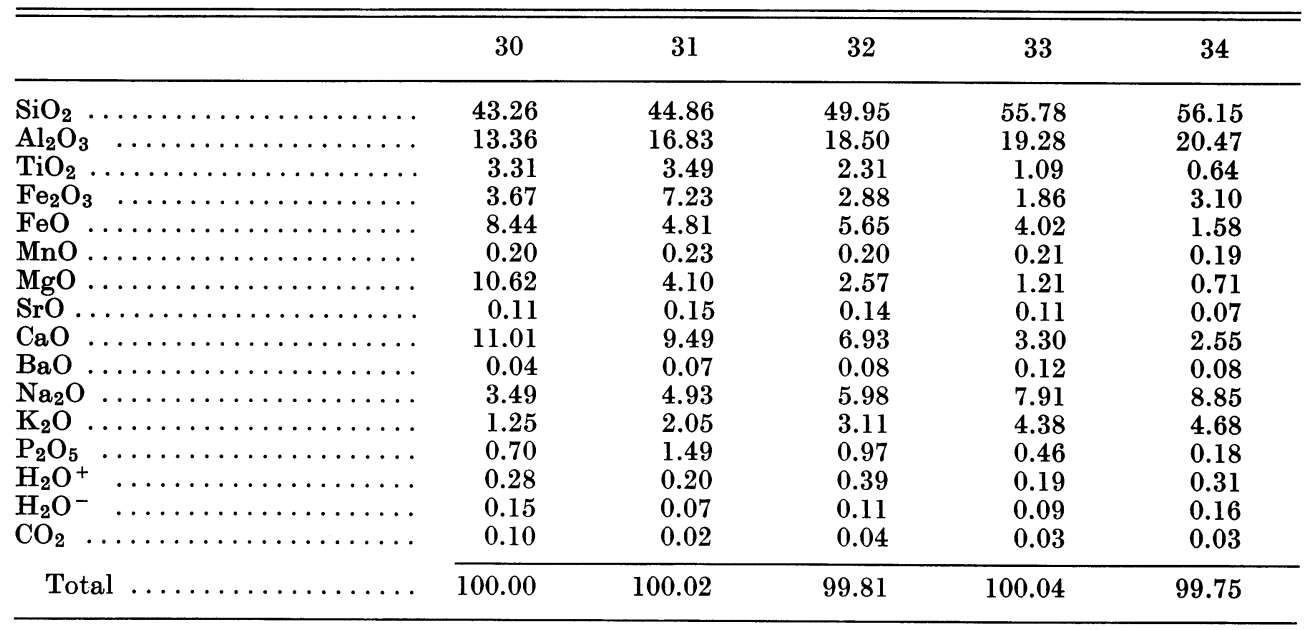

NoTE.-30, Average basanitoid (table 1, nos. 1-12); 31, average low-silica trachybasalt (table 2, nos. 13-15); 32, average high-silica trachybasalt (table 2 , nos. 16-18); 33 , average anorthoclase phonolite (table 3 , nos. 19-22); and 34 , average phonolite (table 4, nos. 23-28).

and trachybasalts, but the trends are reversed in the phonolites, and $\mathrm{Ba}$ and $\mathrm{Sr}$ decline with increasing $\mathbf{K}$.

\section{DISCUSSION}

Magmatic differentiation.-The variations of major, minor, and trace elements support a differentiation model controlled by fractional crystallization from alkali olivine basalt $\rightarrow$ trachybasalt $\rightarrow$ phonolite. The basanitoids contain phenocrysts of olivine, clinopyroxene, and opaque minerals, and the crystallization of these phases governed the early differentiation trend. Although there may have been original differences in the basanitoid parental magmas, the scatter in the points for $\mathrm{MgO}$ (fig. 4) probably is largely the result of settling of olivine. The $\mathrm{MgO}$ content of the basanitoids ranges from $7.8 \%$ to $13 \%$ with a corresponding range in $\mathrm{Ni}$ content from less than 150 to $300 \mathrm{ppm}$ (table 5).

The differentiation trends may be seen in the variations of major and trace constituents in figures 10 and 11 in which averages for the principal rock types are plotted against $\mathrm{K}_{2} \mathrm{O}$. The diagrams show the close relationship between the low silica trachybasalts and the basanitoids. Removal of olivine, clinopyroxene, and opaque oxides enriched the liquid in $\mathrm{Rb}$, $\mathrm{Zr}, \mathrm{Sr}, \mathrm{Ba}$, and others (fig. 10); V, Co, and $\mathrm{Cu}$ were depleted (fig. 11); $\mathrm{P}_{2} \mathrm{O}_{5}$ was notably enriched, and to a lesser extent, also $\mathrm{TiO}_{2}$ and $\mathrm{Al}_{2} \mathrm{O}_{3} ; \mathrm{Rb}, \mathrm{La}$, and $\mathrm{Zr}$ (fig. 10) were enriched progressively with a sharp increase in the phonolites. $\mathrm{Sr}$ attained maximum concentration in the low-silica trachybasalts, and was strongly controlled by crystallization of plagioclase. $\mathrm{Ba}$ was progressively enriched from the basanitoids through the trachybasalts and anorthoclase phonolites in which it is concentrated in the anorthoclase (Mountain 1925; Boudette and Ford 1966; Treves 1967).

Analyses of other mineral phases are in progress, and these will permit a more quantitative treatment of the magmatic differentiation processes. The preliminary chemical results, together with the major and trace-element analyses of this paper, indicate that the crystalizatlion of olivine, 


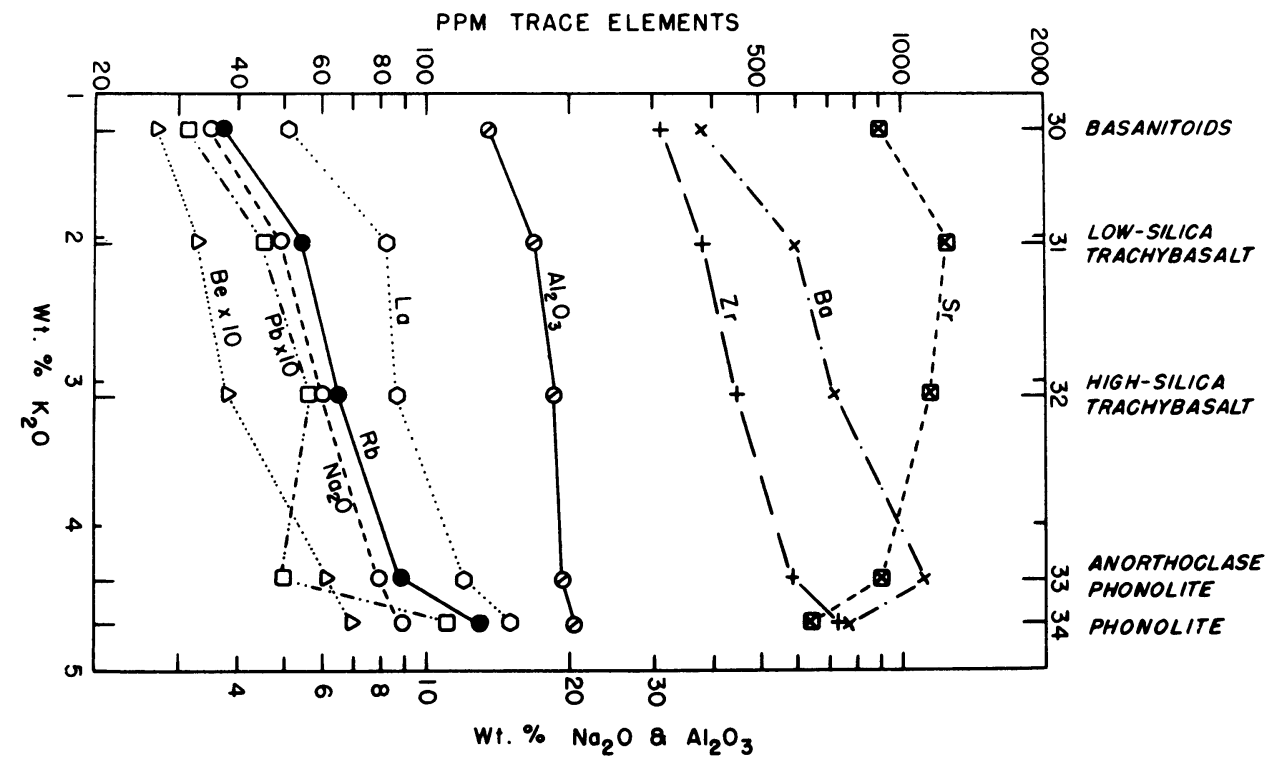

Frg. 10.-Variations of $\mathrm{Na}_{2} \mathrm{O}, \mathrm{Al}_{2} \mathrm{O}_{3}, \mathrm{Sr}, \mathrm{Ba}, \mathrm{Zr}, \mathrm{La}, \mathrm{Rb}, \mathrm{Pb}$, and ${ }^{\circ} \mathrm{Be}$ with $\mathrm{K}_{2} \mathrm{O}$ in principal rock types.

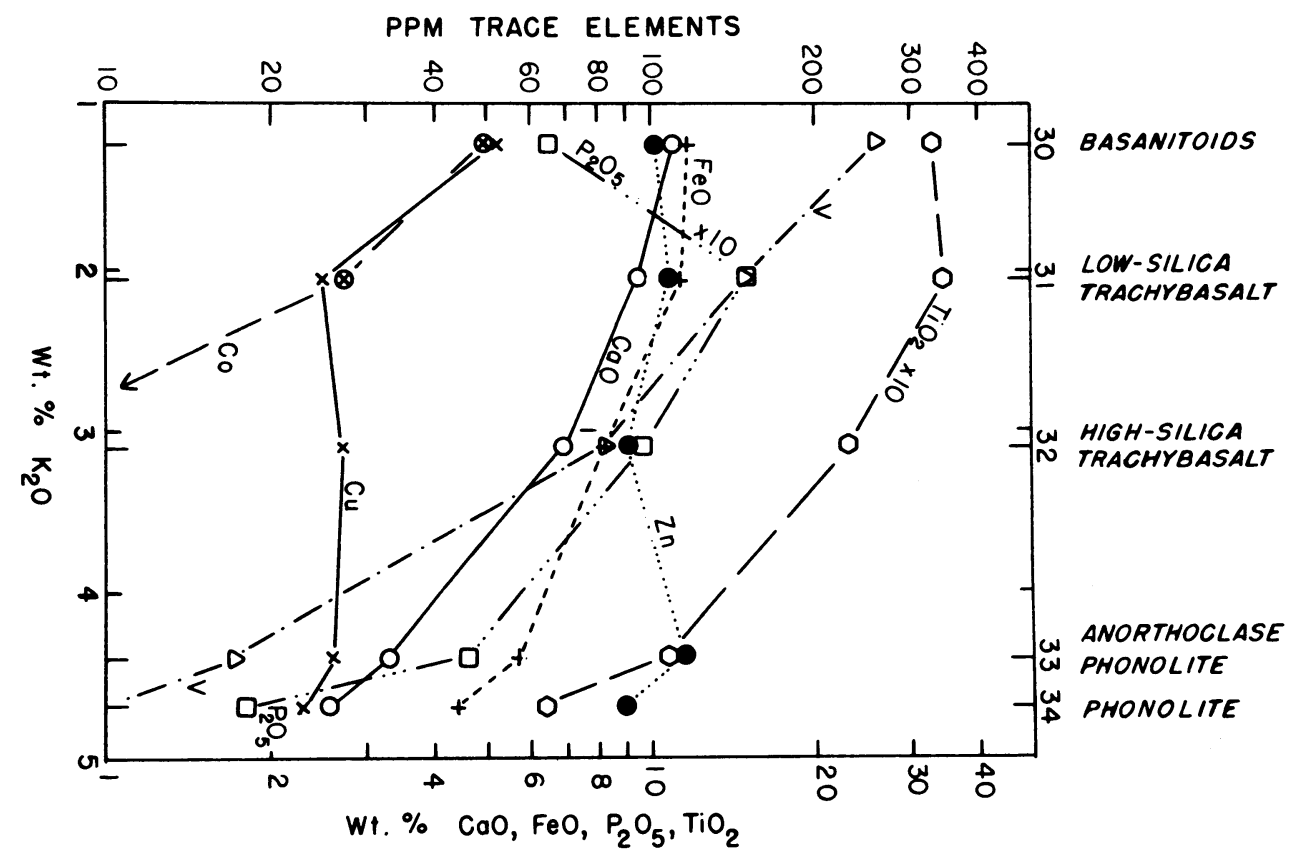

FIg. 11.-Variations of $\mathrm{CaO}, \mathrm{FeO}, \mathrm{P}_{2} \mathrm{O}_{5}, \mathrm{TiO}_{2}, \mathrm{~V}, \mathrm{Zn}, \mathrm{Cu}$, and $\mathrm{Co}$ with $\mathrm{K}_{2} \mathrm{O}$ in principal rock types. 
clinopyroxene, and opaque minerals clearly controlled the early stages of differentiation, giving way to clinopyroxene, apatite, and opaques, with plagioclase, kaersutite, and anorthoclase becoming later phases.

Parental magma.-Gast (1968) demonstrated that trace elements-particularly the large cations $\mathrm{Rb}, \mathrm{Ba}$, and $\mathrm{Sr}$, and the rare earths-are useful in formulating a model for the derivation of basaltic liquids by partial melting of peridotitic mantle. A large degree $(20 \%-30 \%)$ of partial melting would produce a tholeiitic magma; a small degree $(3 \%-7 \%)$ would yield alkali-rich basaltic liquid. The origin of alkali-basalt magma is more fully discussed by Kay (Kay and Gast 1973) who suggests that nepheline normative alkali basalts, similar in composition to the basanitoids of the Ross Island vicinity, may be derived by a small degree $(1 \%$ $2 \%$ ) of partial melting of hydrous garnet peridotite near the top of the asthenosphere.

The ${ }^{87} \mathrm{Sr} /{ }^{86} \mathrm{Sr}$ data support the derivation of the basanitoid magma from mantle sources. Halpern (1969) determined ${ }^{87} \mathrm{Sr} /{ }^{86} \mathrm{Sr}$ ratios for an ultramafic nodule and the host basalt from the McMurdo area and for two ultramafic nodules from Mt. Perkins in the Ford Ranges and concluded from the ratios of 0.7030 to 0.7034 that the nodules and basalt probably are cogenetic. Jones and Walker (1972) reported a large number of $\mathrm{Sr}$ isotope ratios for volcanic rocks from Southern Victoria Land. The samples include representatives of the principal rock types from the Ross Island vicinity, and all have ${ }^{87} \mathrm{Sr} /{ }^{86} \mathrm{Sr}$ ratios in the range from 0.7020 to 0.7048 . The $\mathrm{Sr}$ isotope ratios support the magmatic differentiation explanation for the rock series and are in agreement with data for alkalic rocks in other regions (Hedge 1966; Peterman and Hedge 1971).

Petrologic comparisons.-As would be expected, there are marked similarities between the volcanic rocks of the Ross
Island vicinity and those of the Hallett province (Hamilton 1972). The flows in the Hallett region show the Ross Island trend: alkalic olivine basalt $\rightarrow$ trachybasalt $\rightarrow$ phonolite, but as Hamilton $(1972$, p. C59) indicates, there probably is a second rock series with the sequence: olivine basalt $\rightarrow$ latite $\rightarrow$ trachyte $\rightarrow$ quartz trachyte. If the composition of the trachyte from Mt. Cis in the Ross Island area has not been strongly altered by contamination, it may well belong to this second differentiation series. The analyzed samples from the Ross Island vicinity are less altered, with low ferric/ferrous iron ratios, and with little or no normative hematite compared with the Hallett volcanics. Hamilton (1972) attributes the oxidation to steam generated during eruptions beneath ice sheets in the Hallett region; whereas the eruptions in the Ross Island vicinity in large part were subaerial.

The basanitoids and derivatives in the Ross Island region are chemically similar to volcanic rocks in other areas, such as the Comores (Strong 1972a, 1972b, Flower 1973; Thompson and Flower 1971). In an AMF diagram (fig. 12), the analyses from Ross Island plot close to the curve for the Hawaiian alkalic trend (Macdonald and Katsura 1964). The data points are largely bracketed by the Tristan (Baker et al. 1964) and Hebridean (Tilley and Muir 1962) or Icelandic (Carmichael 1964) curves.

Alkali basalts are related to rift zones on the continents and not to the major oceanic rifts or rises where tholeiitic or low-potassium basaltic magma is generated in large volumes. The association of alkali basalt with rift zones has been discussed in a number of papers, as for example, the East African Rift zone in Ethiopia (Mohr 1971), the Rio Grande depression (Lipman 1969), and the Balcones province, Texas (Spencer 1969). The parallelism of the belt of volcanic centers with the trend of the Transantarctic Mountains (fig. 1) suggests a regional structural control. As 


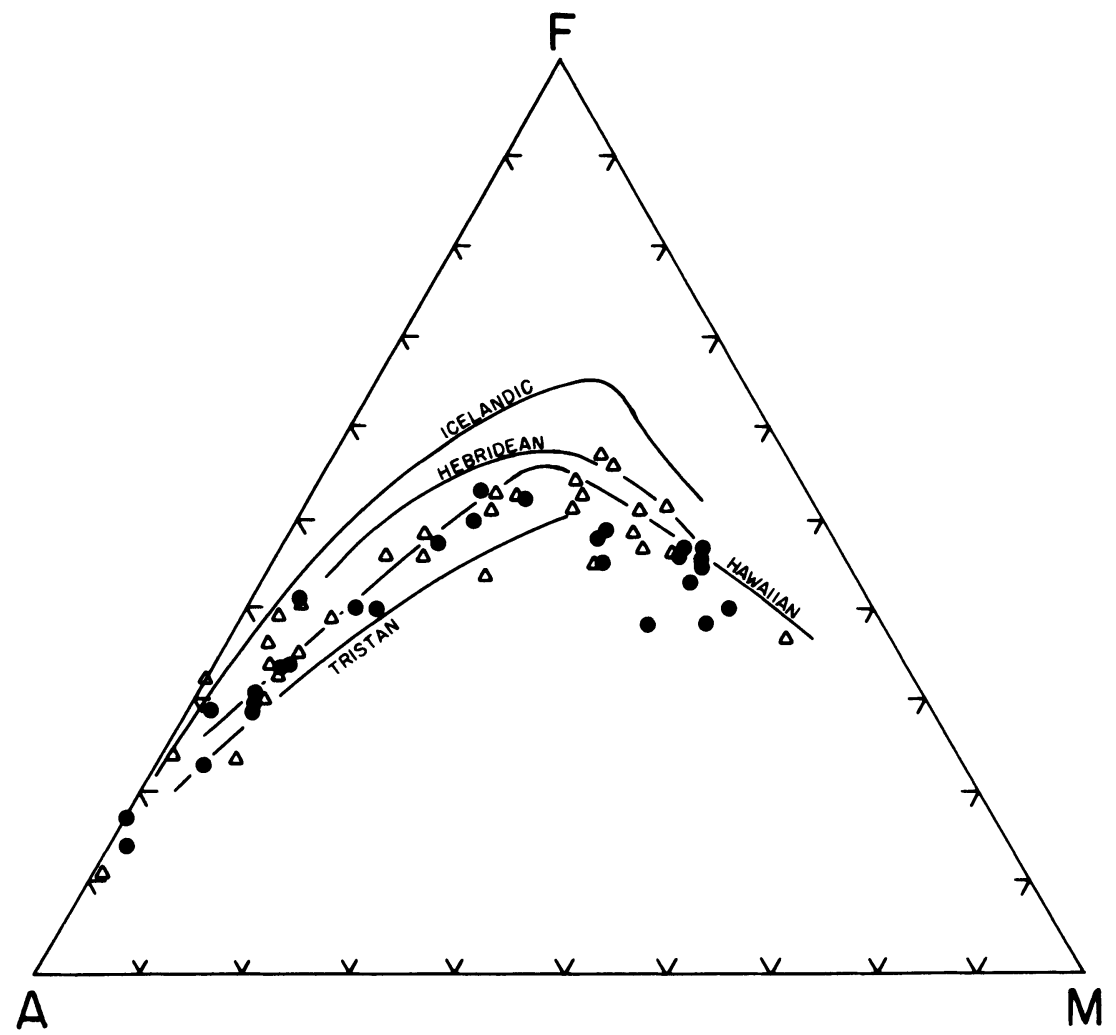

FIG. 12.-AMF diagram (wt\%); symbols for Antarctica rocks are same as in figure 5. Reference trends are Icelandic Thingmuli series (Carmichael 1964); Hebridean (Tilley and Muir 1962); Hawaiian alkalic trend (Macdonald and Katsura 1964); and Tristan (Baker et al. 1964).

in many other parts of the world, the alkalic rocks of the Antarctic belt probably are related to tensional forces that may have permitted rapid ascent of the magma.

ACKNowledgments.-We thank J. B. Bodkin, J. C. DeVine, and R. J. Pottorf for assistance with the chemical work and C. E. Hedge for the isotope-dilution determinations of $\mathrm{Rb}$ and $\mathrm{Sr}$ on the basanitoid composite.
We thank C. E. Hedge, G. N. Hanson, S. S. Sun, D. S. Barker, and W. Hamilton for their helpful review of the manuscript. This study was supported by the National Science Foundation Office of Polar Programs, Grants C642 and GV36951. Transportation and logistical support were provided by the United States Navy Task Force 43, U.S. Navy Support Force, Antarctica, Antarctica Development Squadron Six, and the U.S. Coast Guard.

\section{APPENDIX}

\section{SAMPLE LOCATION AND DESCRIPTION}

Numbers refer to figures 1,2 , and 3; field numbers in parentheses. All samples are fine-grained and gray to black.

\section{BASANITOIDS}

1, (12167) Younger flow, Brown Peninsula (fig. 3). Olivine phenocrysts $(2 \mathrm{~mm}), 16 \%$; groundmass: clinopyroxene, plagioclase, opaques, olivine, nepheline, and apatite. Minor carbonate and alteration of olivine.

2, (2467) Younger, unglaciated sequence on Mt. Hayward, White Island (fig. 3). Phenocrysts : olivine, $7 \%$; clinopyroxene, $0.1 \%$.

3 , (15670) Younger sequence, summit of Mt. Morning (fig. 3). Large yellowish olivine, $23 \%$; black vitreous clinopyroxene, $13 \%$. 
4, (4267) Older sequence north of Mt. Heine, White Island (fig. 3). Green olivine (3 $\mathrm{mm}), 28 \%$ black clinopyroxene, $6 \%$.

5 , (267) Small vent on the south side of Taylor Valley at western edge of Sollas Glacier (fig. 1). Olivine (1 mm), 9\%; clinopyroxene, $6 \%$. Samples from small vents in this area have been dated at 2.7 m.y. (Armstrong et al. 1968).

6, (10567) Brandau Vent, Royal Society Range (fig. 3). Described by McIver and Gevers (1970, p. 76). Green olivine, 12\%; black clinopyroxene, $13 \%$.

7, (15367) Younger sequence on Cape Crozier, Ross Island (fig. 2). Green olivine, $14 \%$; black clinopyroxene, 7\%; black kaersutite, $4 \%$; subhedral plagioclase $\left(\sim \mathrm{An}_{50}\right), 3 \%$.

8, (15765) Older sequence on Cape Armitage, Ross Island (fig. 2). Large green olivine, $24 \%$; clinopyroxene, $8 \%$; opaque, $4.5 \%$.

9, (11667) Core of a pillow, older flow on Brown Peninsula (fig. 3). Yellowish olivine, $6 \%$; black clinopyroxene, $7 \%$; kaersutite, $7 \%$.

10, (567) Older sequence, Cape Crozier, Ross Island (fig. 2). Olivine, 13\%; clinopyroxene, $14 \%$; kaersutite, $1 \%$.

11, (16170) Summit of Mt. Bird, Ross Island (fig. 2). Yellowish-green olivine $(3 \mathrm{~mm}), 8 \%$; clinopyroxene $(2 \mathrm{~mm}), 3 \%$ in glassy matrix.

12, (7367) Younger sequence, Mt. Melania, Black Island (fig. 3). Small yellowish-green olivine, $2 \%$; clinopyroxene, $3 \%$.

\section{TRACHYBASALTS}

13, (14870) Brownish-black, fine-grained; Mt. Terra Nova, Ross Island (fig. 2). Phenocrysts of subhedral plagioclase $\left(\sim \mathrm{An}_{49}\right)$, $22 \%$; small olivine, $1.5 \%$. Groundmass: clinopyroxene, opaques, apatite, and glass.

14, (14770) Same locality as No. 13. Hornblende, $10 \%$; plagioclase ( An $\left.\mathrm{An}_{52}\right), 4 \%$; clinopyroxene, $3 \%$; opaque, $2.5 \%$. Groundmass: clinopyroxene, plagioclase, opaque, and glass.

15, (12765) Basalt Hill, southeast of Cape Royds, Ross Island (fig. 2). Basalt of Smith (1954, p. 99). Plagioclase $\left(\sim \mathrm{An}_{50}\right), 37 \%$; clinopyroxene, $8 \%$; olivine, $2 \%$. Groundmass: clinopyroxene, plagioclase, opaque, and apatite.

16, (7467) Near Mt. Melania, Black Island (fig. 3). Plagioclase $\left(\sim \mathrm{An}_{56}\right), 38 \%$; opaque, $6 \%$; olivine, $3 \%$. Groundmass largely glass with plagioclase, opaque, olivine, clinopyroxene, and apatite.

17, (14167) Miers Valley (fig. 3). Large subhedral phenocrysts of plagioclase $\left(\sim \mathrm{An}_{53}\right), 27 \%$; clinopyroxene, $5 \%$; opaque, $3 \%$; olivine, $2 \%$.

18, (201) Tryggve Point (fig. 2). Large, subhedral zoned plagioclase phenocrysts $\left(\sim \mathrm{An}_{37}\right), 33 \%$; olivine, $7 \%$; clinopyroxene, $2 \%$; opaque, minor. Groundmass : plagioclase, clinopyroxene, olivine, opaques.

\section{ANORTHOCLASE PHONOLITES}

19, (14467) Cape Evans, Ross Island (fig. 2); kenyte of Smith (1954). Phenocrysts : anorthoclase, $42 \%$; clinopyroxene, $1.6 \%$. Groundmass : anorthoclase, $63 \%$; clinopyroxene, $37 \%$; opaque, apatite, and nepheline.

20, (13770) Summit of Mt. Erebus, Ross Island (fig. 2). Anorthoclase, $31 \%$; clinopyroxene, $1 \%$. Groundmass largely glass with some clinopyroxene, apatite, nepheline, and opaques.

21, (15267) Youngest flow of anorthoclase phonolite at Cape Royds, Ross Island (fig. 2); leucite kenyte of Prior (1907); anorthoclase trachyte of Boudette and Ford (1966). Phenocrysts: anorthoclase, 38\%; clinopyroxene, $1 \%$; olivine $0.4 \%$.

22, (15167) From the same flow as no. 21. Phenocrysts: anorthoclase, $30 \%$; clinopyroxene, $1 \%$; olivine, $0.5 \%$. Groundmass largely glass.

\section{HORNBLENDE AND PYROXENE PHONOLITES}

23, (15067) Flow within the older sequence near the summit of Mt. Discovery (fig. 3). Phenocrysts: large plagioclase ( $\left.\sim \mathrm{An}_{26}\right), 31 \%$; opaques, $2 \%$; clinopyroxene, $1 \%$; olivine, trace. Groundmass: clinopyroxene, plagioclase, minor apatite and opaques.

24, (16070) Mt. Bird, Ross Island (fig. 2). Phenocrysts: anorthoclase, $20 \%$; plagioclase $\left(\sim \mathrm{An}_{28}\right), 12 \%$; clinopyroxene, $4 \%$; kaersutite, $2 \%$. Groundmass: anorthoclase, clinopyroxene, and opaques.

25, (15965) Observation Hill, Ross Island (fig. 2); hornblende trachyte of Prior (1907). Phenocrysts: anorthoclase, $32 \%$; hornblende, $10 \%$; plagioclase, $3 \%$; clinopyroxene, $1 \%$,

26 , (5867) Light olive-gray vitric phonolite from Mt. Aurora, Black Island (fig. 3). Partially devitrified, somewhat vesicular glass with finely disseminated opaques and a few microlites of plagioclase. 


\section{S. S. GOLDICH, S. B. TREVES, N. H. SUHR, AND J. S. STUCKLESS}

27, (8567) Glomeroporphyry from Minna Bluff (fig. 3). Anorthoclase phenocrysts, 4\%. Groundmass largely anorthoclase, clinopyroxene, and trace of opaques.

28, (1167) Gray, fine-grained, vesicular rock from Post Office Hill, Cape Crozier, Ross Island (fig. 2). Phenocrysts: anorthoclase, $17 \%$; reddish-brown hornblende, $7 \%$.

\section{TRACHYTE}

29, (13867) Fine-grained, olive-gray rock from Mt. Cis, near Cape Royds, Ross Island (fig. 2); trachyphonolite of Jensen (1916), phonolitic trachyte of Smith (1954). Clinopyroxene phenocrysts, about $1 \%$. Groundmass: anorthoclase, clinopyroxene, opaques, apatite, and carbonate.

\section{REFERENCES CITED}

Armstrong, R. L. ; Hamilton, W. ; and Denton, G. H., 1968, Glaciation in Taylor Valley, Antarctica, older than 2.7 million years: Science, v. 159, p. 187-189.

Baker, P. E.; Gass, I. G.; Harris, P. G.; and LeMaitre, R. W., 1964, The volcanological report of the Royal Society expedition to Tristan da Cunha, 1962 : Royal Soc. (London) Philos. Trans., ser. A, no. 256, p. 439-578.

Boudette, E. L., and Ford, A. B., 1966, Physical properties of anorthoclase from Antarctica: Am. Mineralogist, v. 51, p. 1374 1387.

Carmichael, I. S. E., 1964, The petrology of Thingmuli, a Tertiary volcano in eastern Iceland: Jour. Petrology, v. 5, p. 409-434.

Cole, J. W., and Ewart, A., 1968, Contributions to the volcanic geology of the Black Island, Brown Peninsula, and Cape Bird areas, McMurdo Sound, Antarctica: New Zealand Jour. Geology and Geophysics, v. 11, p. 793 828.

Compston, W.; McDougall, I.; and Heier, K. S., 1968, Geochemical comparison of the Mesozoic basaltic rocks of Antarctica, South Africa, South America and Tasmania: Geochim. et Cosmochim. Acta, v. 32, p. 129-149.

Flower, M. F. J., 1973, Evolution of basaltic and differentiated lavas from Anjouan, Comores Archipelago: Contr. Mineralogy and Petrology, v. 38, p. 237-260.

Forbes, R. B., 1963, Ultrabasic inclusions from the basalts of the Hut Point area, Ross Island, Antarctica: Bull. volcanol., v. 26, p. 13-21.

$\longrightarrow$, and Kuno, H., 1965, The regional petrology of peridotite inclusions and basaltic host rocks: I. U. G. S. Upper Mantle Symposium, New Delhi 1964, Copenhagen, p. 161180.

GAST, P. W., 1968, Trace element fractionation and the origin of tholeiite and alkaline magma types: Geochim. et Cosmochim. Acta, v. 32, p. 1057-1086.

HALPERN, M., $1969,{ }^{87} \mathrm{Sr} /{ }^{86} \mathrm{Sr}$ ratios of ultramafic nodules and host basalt from the McMurdo area and Ford Ranges, Antarctica: Antarctic Jour. U.S., v. 4, p. 206.

HamiltoN, W., 1972, The Hallett volcanic province, Antarctica: U.S. Geol. Survey Prof. Paper 456-C, 62 p.

HeDGE, C., 1966, Variations in radiogenic strontium found in volcanic rocks: Jour. Geophys. Research, v. 71, p. 1214-1217.

INGAMELLS, C. O., and SuHR, N. H., 1963 , Chemical and spectrochemical analysis of standard silicate samples: Geochim. et Cosmochim. Acta, v. 27, p. 897-910.

JENSEN, H. I., 1916, Report on the petrology of the alkaline rocks of Mount Erebus, Antarctica: British Antarctic Expedition 1907-9: Rept. Sci. Inv. Geology, v. 2, p. 93-128.

Jones, L. M., and Walker, R. L., 1972, Geochemistry of the McMurdo volcanics, Victoria Land: Part 1, Strontium isotope composition: Antarctic Jour. U.S., v. 7, p. 142-144.

KAY, R. W., and GAST, P. W., 1973, The rare earth content and origin of alkali-rich basalts : Jour. Geology, v. 81, p. 653-682.

Lipman, P. W., 1969, Alkalic and tholeiitic basaltic volcanism related to the Rio Grande depression, southern Colorado and northern New Mexico: Geol. Soc. America Bull., v. 80, p. 1343-1354.

Macdonald, G. A., and Katsura, T., 1964, Chemical composition of Hawaiian lavas: Jour. Petrology, v. 1, p. 172-177.

McDougall, I., 1963, Potassium-argon age measurements on dolerites from Antarctica and South Africa: Jour. Geophys. Research, v. 68, p. 1535-1545.

McIver, J. R., and Gevers, T. W., 1970, Volcanic vents below the Royal Society Range, Central Victoria Land, Antarctica: Geol. Soc. South Africa, v. 73, p. 65-68.

Medlin, J. H.; SuHr, N. H. ; and Bodkin, J. B., 1970 , Determination of rubidium in silicate materials by atomic absorption spectrophotometry: Chem. Geology, v. 6, p. 143-148.

MoHr, P. A., 1971, Ethiopian rift and plateau: some volcanic petrochemical differences: Jour. Geophys. Research, v. 76. p. 1967-1985.

Mountain, E. D., 1925, Potash-oligoclase from Mt. Erebus, Antarctica, and anorthoclase from Mt. Kenya, East Africa: Mineralog. Mag., v. 20, p. 331-345.

Peterman, Z. E., and Hedge, C. E., 1971 , Related strontium isotopic and chemical variations in oceanic basalts: Geol. Soc. America Bull., v. 82, p. 493-500.

PrIor, G. T., 1902, Report on the rock-specimens collected by the "Southern Cross" Antarctic Expedition: Brit. Mus. (Nat. Hist.), p. 321-332. 


\section{GEOCHEMISTRY OF CENOZOIC VOLCANIC ROCKS}

1907, Report on rock specimens collected during the "Discovery" Antarctica Expedition, 1901-1904: Brit. Mus. Rep. 1 (Geology), p. 101-123.

Smrth, W. C., 1954, The volcanic rocks of the Ross Archipelago: British Antarctic "Terra Nova" Expedition, 1910: Nat. Hist. Rept. Geology, v. 2, p. 1-107.

Spencer, A. B., 1969, Alkalic igneous rocks of the Balcones province, Texas: Jour. Petrology, v. 10, p. 272-306.

Strong, D. F., 1972 $a$, The petrology of the lavas of Grande Comore: Jour. Petrology, v. 13, p. 181-217.

1972b, Petrology of the Island of Moheli, Western Indian Ocean: Geol. Soc. America Bull., v. 83, 389-405.
Thompson, J. A., 1916, Report on the inclusions of the volcanic rocks of the Ross Archipelago, British Antarctic Expedition 1907-1909, Geol. Rept. 2, p. 129-148.

Thompson, R. N., and Flower, M. F. J., 1971, One-atmosphere melting and crystalline relations of lava from Anjouan, Comores Archipelago, Western Indian Ocean: Earth and Planetary Sci. Letters, v. 12, p. 97-107.

Tilley, C. E., and Murr, I. D., 1962, The Hebridean plateau magma type: Edinburgh Geol. Soc., Trans., v. 19, p. 208-215.

Treves, S. B., 1967, Volcanic rocks from the Ross Island, Marguerite Bay, and Mount Weaver areas, Antarctica: Japanese Antarctic Research Expedition (JARE) Scientific Reports, v. 1, p. 136-149. 